\title{
Evaluating ecosystem response to oyster restoration and nutrient load reduction with a multispecies bioenergetics model
}

\author{
RS Fulford \\ DL Brietburg \\ Mark Luckenbach \\ Virginia Institute of Marine Science \\ RIE Newell
}

Follow this and additional works at: https://scholarworks.wm.edu/vimsarticles

Part of the Ecology and Evolutionary Biology Commons, and the Marine Biology Commons

\section{Recommended Citation}

Fulford, RS; Brietburg, DL; Luckenbach, Mark; and Newell, RIE, Evaluating ecosystem response to oyster restoration and nutrient load reduction with a multispecies bioenergetics model (2010). Ecological Applications, 20(4), 915-934. doi:10.1890/08-1796.1

This Article is brought to you for free and open access by the Virginia Institute of Marine Science at W\&M ScholarWorks. It has been accepted for inclusion in VIMS Articles by an authorized administrator of W\&M ScholarWorks. For more information, please contact scholarworks@wm.edu. 


\title{
Evaluating ecosystem response to oyster restoration and nutrient load reduction with a multispecies bioenergetics model
}

\author{
Richard S. Fulford, ${ }^{1,5}$ Denise L. Breitburg, ${ }^{2}$ Mark Luckenbach, ${ }^{3}$ and Roger I. E. Newell ${ }^{4}$ \\ ${ }^{1}$ Department of Coastal Sciences, University of Southern Mississippi, Gulf Coast Research Laboratory, \\ 703 East Beach Drive, Ocean Springs, Mississippi 39564 USA \\ ${ }^{2}$ Smithsonian Environmental Research Center, 647 Contees Wharf Road, Edgewater, Maryland 21037 USA \\ ${ }^{3}$ Virginia Institute of Marine Science Eastern Shore Laboratory, P.O. Box 350, Wachapreague, Virginia 23480 USA \\ ${ }^{4}$ Horn Point Laboratory, University of Maryland Center for Environmental Science, P.O. Box 775 , Cambridge, Maryland 21613 USA
}

Abstract. Many of the world's coastal ecosystems are impacted by multiple stressors each of which may be subject to different management strategies that may have overlapping or even conflicting objectives. Consequently, management results may be indirect and difficult to predict or observe. We developed a network simulation model intended specifically to examine ecosystem-level responses to management and applied this model to a comparison of nutrient load reduction and restoration of highly reduced stocks of bivalve suspension feeders (eastern oyster, Crassostrea virginica) in an estuarine ecosystem (Chesapeake Bay, USA). Model results suggest that a $50 \%$ reduction in nutrient inputs from the watershed will result in lower phytoplankton production in the spring and reduced delivery of organic material to the benthos that will limit spring and summer pelagic secondary production. The model predicts that low levels of oyster restoration will have no effect in the spring but does result in a reduction in phytoplankton standing stocks in the summer. Both actions have a negative effect on pelagic secondary production, but the predicted effect of oyster restoration is larger. The lower effect of oysters on phytoplankton is due to size-based differences in filtration efficiency and seasonality that result in maximum top-down grazer control of oysters at a time when the phytoplankton is already subject to heavy grazing. These results suggest that oyster restoration must be achieved at levels as much as 25 -fold present biomass to have a meaningful effect on phytoplankton biomass and as much as 50 -fold to achieve effects similar to a $50 \%$ nutrient load reduction. The unintended effect of oyster restoration at these levels on other consumers represents a trade-off to the desired effect of reversing eutrophication.

Key words: ecosystem; eutrophication; food web; modeling; oyster; restoration.

\section{INTRODUCTION}

Natural resource management in aquatic ecosystems is shifting from an emphasis on individual problems towards a more adaptive and sustainable paradigm of restoring and conserving ecosystem services (National Marine Fisheries Service 1999, Ptacnik et al. 2005). This paradigm more strongly integrates management with spatial and temporal patterns in ecosystem structure, but it also brings new challenges for defining clear management targets and benchmarks that are inclusive of a broad range of environmental issues. In particular, interest in ecosystem-based approaches to management of highly impacted coastal ecosystems has increased with a growing recognition of the overlapping goals and approaches of living resource restoration, improving water quality, and fisheries management.

Cultural eutrophication has increased in coastal and estuarine systems over the last 50 years, resulting in

Manuscript received 22 October 2008; revised 12 August 2009; accepted 13 August 2009. Corresponding Editor (ad hoc): R. R. Christian.

${ }^{5}$ E-mail: richard.fulford@usm.edu declining water quality and shifts from benthic-dominated to pelagic-dominated primary production in many estuaries throughout the world (Nixon 1995, Cloern 2001, Kemp et al. 2005). Efforts to reduce or reverse this trend have generally focused on reducing the input of new nutrients and organic material (Jordan et al. 2003, Fear et al. 2004, Neumann and Schemewski 2005). Overfishing, disease, and habitat degradation have greatly reduced biomass of bivalve suspension feeders, especially oysters, in some of the same systems prior to major increases in anthropogenic nutrient loading (Mackenzie et al. 1997). Restoration of important bivalve species is a management objective in many systems for rebuilding important commercial fisheries and to restore healthy benthic habitat that increases the transfer of benthic secondary production to pelagic consumers (Coen et al. 1999, 2007). Increased abundances of bivalve suspension feeders may also reduce concentrations of phytoplankton and other suspended particulates, allowing a return to higher rates of benthic primary production (Newell and Ott 1998, Nakamura and Kerciku 2000, Cressman et al. 2003). Restoration of benthic suspension-feeder biomass has therefore been 
proffered as a potentially important supplement to nutrient reduction strategies to reverse cultural eutrophication (Officer et al. 1982, Newell et al. 2005).

Reducing nutrient loads and restoring benthic suspension-feeder populations both have the potential to decrease phytoplankton biomass in the water column and can be considered complementary management strategies. However, both actions are likely to have substantial direct and indirect effects on trophic structure that can be difficult to predict. Reductions in nutrient loads should reduce the specific rate of pelagic primary production (Neumann and Schemewski 2005), and increases in total benthic filtration should reduce phytoplankton standing stocks, both of which reduce suspended particulates and provide more light penetration to support benthic primary producers (Newell 2004). The efficacy of top-down control of phytoplankton biomass and increases in benthic primary production have been demonstrated in freshwater systems both with and without nutrient enrichment (Carpenter et al. 1995, 2001). Yet, effects on phytoplankton specific production rate (i.e., bottom-up) and effects on phytoplankton biomass (i.e., top-down) may have very different influences on energy flow through food webs due to potential differences in how these two pathways impact other consumers. A model-based examination of synergistic outcomes of oyster restoration and nutrient load reductions is, therefore, a useful approach for comparing and contrasting the effects of these two potential management actions.

Chesapeake Bay, located on the U.S. Atlantic coast, has experienced a long history of cultural eutrophication resulting in increased phytoplankton biomass (Kemp et al. 2005), decreased water clarity (Gallegos 2001), increased severity and extent of seasonal hypoxia (Breitburg 1990, Boicourt 1992, Hagy et al. 2004), and decreased biomass of submerged aquatic vegetation (Kemp et al. 1983, Orth and Moore 1983, Orth et al. 2002). Chesapeake Bay has also been subjected to direct impacts on its living resources. In particular, the abundance of eastern oysters (Crassostrea virginica) has declined dramatically as a result of overharvesting, disease, and siltation of oyster reef habitat (Jordan et al. 2002).

Recognition of these problems has led to an extensive effort to reduce the delivery of nutrients into Chesapeake Bay (Correll et al. 1999, 2000, Jordan et al. 2003) as well as research and public interest in oyster restoration (Brumbaugh et al. 2000, National Research Council 2004, Newell et al. 2005). Prior to commercial exploitation, the oyster population in Chesapeake Bay was two to three orders of magnitude higher than its present levels (Newell 1988, Jordan and Coakley 2004). The intense filtration activity associated with this large oyster population is thought to have made a major contribution to the control of phytoplankton abundance under historic conditions of nutrient and sediment delivery (Newell 1988, Newell and Ott 1998). If these historical abundances of oysters were still present, they might have made Chesapeake Bay more resilient to anthropogenic nutrient inputs (Carpenter et al. 1995, Newell et al. 2005). Increased oyster biomass has also been associated with increased benthic secondary production (Coen et al. 1999, Luckenbach et al. 2005, Rodney and Paynter 2006), alteration of nutrient recycling rates (Newell et al. 2005), decreased pelagic primary production (Cloern 1982, Officer et al. 1982, Dame 1996, Souchu et al. 2001), and increased reproductive success of the sea nettle, Chrysaora quinquecirrha (Breitburg and Fulford 2006).

Trophic network modeling provides a powerful tool for examining the direct and indirect effects of multiple management actions. Previous examination of trophic effects of increasing oyster biomass in Chesapeake Bay utilizing a network model suggested that increased oyster biomass will result in decreased phytoplankton biomass, increased benthic primary production, decreased biomass of gelatinous zooplankton, and increased biomass of both forage fishes and top carnivores (Ulanowicz and Tuttle 1992). However, Ulanowicz and Tuttle (1992) did not address seasonality, foraging efficiency, consumer diet flexibility, or increases in benthic habitat in their analysis, and considered only a 2.5-fold change in oyster density.

We developed a trophic network simulation model intended to capture important features of the benthicpelagic food web of Chesapeake Bay and extend previous examinations of the effects of increasing oyster biomass and decreasing nutrient inputs on energy flow. We focus primarily on the pelagic food web of a composite of representative tributaries in the discussion of model results because oyster feeding is tightly coupled to the pelagic food web and to highlight potential effects of oyster restoration on important consumer species. Our trophic simulation model (TroSim) was designed to capture the effects of seasonality of production, sizeselective filtration efficiency, and diet flexibility of consumers but it does not explicitly consider other processes such as hydrodynamic factors, changes in nutrient recycling rates, or hypoxia.

Our objectives were to (1) forecast the potential net effect of oyster reef restoration on the pelagic food web under a range of potential changes in oyster biomass, (2) contrast the effects of oyster restoration to those predicted for a reduction in nutrient loads in our reference system, and (3) evaluate oyster restoration as an ecosystem management tool.

\section{Methods \\ Model structure}

The trophic simulation model (TroSim) we developed was based on an existing general mass-balance simulation model designed for toxicological risk assessment (CASM-COASTES; Bartell et al. 1999, Bartell 2003). The original model framework, as described by Eqs. 1-3 below, was adapted into TroSim, which provides more 
flexibility in model response to changes in food web structure and allows for model perturbation at multiple trophic levels. Primary modifications of the CASM framework were inclusion of more explicit linkages between detrital pools, a prey refuge term (sensu Walters and Juanes 1993), inclusion of non-trophic links among functional groups (e.g., nauplii are a link between meso- and microzooplankton), and adaptation of the model to a shorter time step. Details are given on these adaptations below. Additional details of model structure are in Appendix A. TroSim is well suited for comparing and contrasting the effects of disparate management strategies on ecosystem structure. Food web interactions are simulated, while the role of oysters in creating reef habitat for ecologically important species is built into model assumptions.

TroSim is a carbon budget model that operates on a 0.1-day time step to describe carbon transfer between trophic groups based on the energetic needs of producers and consumers (Fig. 1) and dietary preferences. Producer and consumer functional groups are defined based on tractable levels of taxonomic specificity (Tables 1 and 2).

The daily change in biomass $\left(B_{j}, \mathrm{~g} \mathrm{C} / \mathrm{m}^{3}\right)$ for producer group $j$ was calculated as the difference between total daily production of producer $j$ on day $i\left(P_{j, i} \mathrm{~g} \mathrm{C} / \mathrm{d}\right)$ and losses due to respiration $\left(R_{j}, \mathrm{~d}^{-1}\right)$, sinking $\left(s_{j}, \mathrm{~d}^{-1}\right)$, nonpredatory mortality (i.e., senescence; $m_{j}, \mathrm{~d}^{-1}$ ) and predation by consumers $\left(\operatorname{Pr}_{j}\right)$ :

$$
\begin{aligned}
\delta B_{j} / \delta t= & B_{j} \times\left(P_{\max } \times[f(t) \times g(l) \times n(d)]^{1 / 3} \times\left[1-R_{j}\right]\right) \\
& -m_{j}-s_{j}-\operatorname{Pr}_{j} .
\end{aligned}
$$

Total daily production is the product of a producergroup-specific rate of maximum daily production $\left(P_{\max }\right.$, g $\left.\mathrm{C} \cdot \mathrm{g} \mathrm{C}^{-1} \cdot \mathrm{d}^{-1}\right)$ and the geometric mean of control factors for temperature $\left(f(t), t=\right.$ daily temperature, $\left.{ }^{\circ} \mathrm{C}\right)$, light availability $(g(l), l=$ daily surface light level, $\mu \mathrm{mol} /$ $\mathrm{m}^{2}$ ), and nutrient availability $\left(n\left(d_{p}\right), d_{p}=\right.$ daily concentration of nutrient $p, \mathrm{mg} / \mathrm{L}$ ).

The daily change in biomass $\left(B_{j}, \mathrm{~g} \mathrm{C} / \mathrm{m}^{3}\right)$ for consumer group $j$ was calculated as the difference between total daily ingestion $\left(I_{j}, \mathrm{~g} \mathrm{C} / \mathrm{d}\right)$ and daily losses due to costs of metabolism $\left(R_{j}\right)$, consumption (SDA), waste production $\left(U_{j}\right)$, reproduction $\left(\mathrm{Rp}_{j}\right)$, losses due to non-predatory mortality $\left(m_{j}\right)$, and total daily consumption of consumer $j$ by other consumers $\left(\operatorname{Pr}_{j}\right)$ :

$$
\delta B_{j} / \delta t=I_{j} \times(1-[\mathrm{SDA}+U])-R_{j}-\mathrm{Rp}_{j}-m_{j}-\operatorname{Pr}_{j} .
$$

Daily ingestion is based on an estimate of maximum daily consumption $\left(C_{\max }, \mathrm{g} \mathrm{C} \cdot \mathrm{g} \mathrm{C}^{-1} \cdot \mathrm{d}^{-1}\right)$ adjusted for water temperature $\left(f(t) t=\right.$ daily water temperature, $\left.{ }^{\circ} \mathrm{C}\right)$ and multiplied by consumer biomass $\left(B_{j, i}\right)$ to calculate total consumption for consumer $j$ on day $i$. Temperature adjustments were specific for each trophic group and based on the dominant species as a function of biomass (Table 2). Maximum daily consumption by oysters was based on a maximum filtration rate $\left(0.55 \mathrm{~m}^{3} \cdot \mathrm{g} \mathrm{C}^{-1} \cdot \mathrm{d}^{-1}\right.$; Newell and Langdon 1996) adjusted for temperature (Fulford et al. 2007) and converted to daily consumption by multiplying filtration rate by total prey biomass.

Temperature-adjusted maximum consumption for consumer group $j$ was then allocated to ingestion of each prey group $k$ based on prey group biomass $\left(\mathrm{Ba}_{k}\right.$ and $\mathrm{Ba}_{x}$ ), consumer- and prey-specific parameters for preference $\left(w_{j, k}\right)$, assimilation efficiency $\left(a_{j, k}\right)$, and handling efficiency $\left(\right.$ he $\left._{j, k}\right)$ :

$$
I_{j, i}=\sum_{k=1}^{n} \frac{B_{j} \times C_{\max } \times f(t) \times w_{j, k} \times a_{j, k} \times \mathrm{he}_{j, k} \times \mathrm{Ba}_{k}}{\sum_{x=1}^{n} \mathrm{Ba}_{x} \times w_{j, x}}
$$

TroSim uses Ivlev's electivity index (Paloheimo 1979) to calculate prey preference and the amount of daily consumption allocated to each prey group was normalized by the preference weighted total biomass of all prey.

\section{Functional groups}

Producers groups.-Phytoplankton was separated by equivalent spherical diameter (ESD) into six functional groups (Table 1). We used size categories rather than taxonomic groupings for phytoplankton because diet composition of suspension feeding organisms in which we were most interested (i.e., eastern oysters and menhaden) is primarily determined by size-based retention efficiency of prey (Newell and Langdon 1996). Analysis of phytoplankton data for Chesapeake Bay suggests that except for picoplankton the relative biomass of phytoplankton size categories changes minimally within each season despite large changes in the taxonomic composition (Fulford et al. 2007). Other historically important primary producers such as submerged aquatic vegetation and microphytobenthos were not included in the model because their current contribution to primary production is minor and there are no data on the trajectory of response of these groups to oyster restoration effects. This simplifying assumption will be further addressed in the discussion.

Phytoplankton biomass $\left(\mathrm{g} \mathrm{C} / \mathrm{m}^{3}\right)$ was calculated by converting total chlorophyll $a(\mathrm{chl} a ; \mu \mathrm{g} / \mathrm{L})$ to carbon (40 g C:g chl $a$; Gallegos 2001). Monthly estimates of total chl $a$ were calculated from monitoring data collected in the Bay from 1986 to 2002 (Chesapeake Bay Program Office, Annapolis, Maryland; data available online). ${ }^{6}$ Biomass data were used to define initial biomass for each phytoplankton size group on model day 1 (1 January) and monthly mean biomass for each size group for model validation. This model validation approach was used for all functional groups. Production and metabolic cost data for each phytoplankton size class were based on allometric rates from the literature and adjusted within the range of data variability to fit the

${ }^{6}\langle$ http://www.chesapeakebay.net/data_plankton.aspx $\rangle$ 


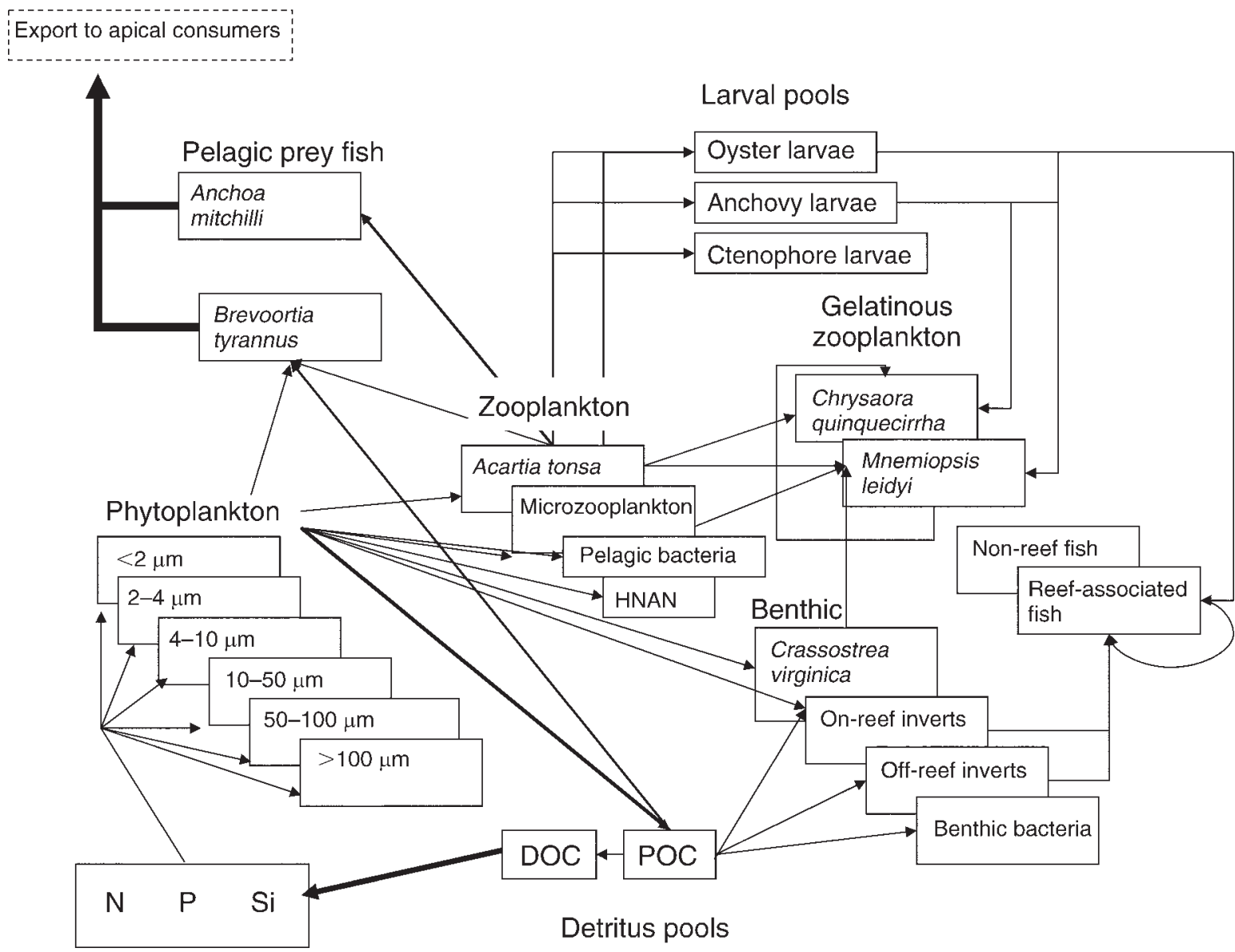

FIG. 1. Network diagram describing carbon flow between functional groups for the trophic simulation model (TroSim) parameterized for Chesapeake Bay. Abbreviations are: DOC, dissolved organic carbon; POC, particulate organic carbon; HNAN, heterotrophic nanoflagellates.

observed seasonal trend for each size group (Banse 1982, Tang 1995).

Consumer groups.-Consumer functional groups were included in six ecological categories: zooplankton, gelatinous zooplankton, pelagic forage fishes, benthic invertebrates, benthic omnivorous fishes, and larval sub-pools. The number of functional groups in each category varied from one to three (Table 2). Microbial dynamics were not explicitly modeled but are included in the form of temperature-mediated functions of the catabolism of particulate and dissolved carbon. Unless otherwise stated biomass data for all consumer groups was estimated from monitoring data as described for phytoplankton (Chesapeake

TABLE 1. Group-specific model input parameters for producer groups $j$.

\begin{tabular}{|c|c|c|c|c|c|c|c|c|c|c|}
\hline & $\begin{array}{c}B_{0} \\
\left(\mathrm{~g} \mathrm{C} / \mathrm{m}^{3}\right)\end{array}$ & $\begin{array}{l}T_{\mathrm{opt}} \\
\left({ }^{\circ} \mathrm{C}\right)\end{array}$ & $\begin{array}{l}T_{\max } \\
\left({ }^{\circ} \mathrm{C}\right)\end{array}$ & $\begin{array}{c}D_{j} \\
(\mu \mathrm{mol} / \\
\left.\mathrm{m}^{2}\right)\end{array}$ & $\begin{array}{c}P_{\max } \\
\left(\mathrm{g} \mathrm{C}^{\mathrm{g}}\right. \\
\left.\mathrm{C}^{-1} \cdot \mathrm{d}^{-1}\right)\end{array}$ & $\left(\mathrm{d}^{-1}\right)$ & $\begin{array}{c}K_{j}(\mathrm{P}) \\
(\mu \mathrm{g} \mathrm{P} / \mathrm{L})\end{array}$ & $\begin{array}{c}K_{j}(\mathrm{~N}) \\
(\mu \mathrm{g} \mathrm{N} / \mathrm{L})\end{array}$ & $\begin{array}{c}M_{j} \\
\left(\mathrm{~d}^{-1}\right)\end{array}$ & $\begin{array}{c}R_{j} \\
\left(\mathrm{~d}^{-1}\right)\end{array}$ \\
\hline \multicolumn{11}{|c|}{ Phytoplankton size } \\
\hline$>100 \mu \mathrm{m}$ & $1.20 \times 10^{-3}$ & 10 & 14.5 & 100 & 0.81 & 0.01 & 3.5 & 35 & 0.1 & 0.05 \\
\hline $50-100 \mu \mathrm{m}$ & $2.20 \times 10^{-2}$ & 10 & 14.5 & 100 & 1.00 & 0.01 & 3.5 & 35 & 0.1 & 0.05 \\
\hline $10-49 \mu \mathrm{m}$ & $2.20 \times 10^{-2}$ & 10 & 14.5 & 100 & 1.11 & 0.01 & 3.5 & 35 & 0.1 & 0.05 \\
\hline $4-9.9 \mu \mathrm{m}$ & $2.20 \times 10^{-2}$ & 10 & 14.5 & 100 & 1.29 & 0.001 & 3.5 & 35 & 0.1 & 0.20 \\
\hline $2-3.9 \mu \mathrm{m}$ & $1.70 \times 10^{-3}$ & 10 & 14.5 & 80 & 1.42 & 0.001 & 3.5 & 35 & 0.1 & 0.40 \\
\hline$<2 \mu \mathrm{m}$ & 4.00 & 24 & 34 & 80 & 1.71 & 0.001 & 3.5 & 35 & 0.1 & 0.40 \\
\hline
\end{tabular}

Notes: Parameters are initial values of group biomass $\left(B_{0}\right)$, optimal $\left(T_{\mathrm{opt}}\right)$ and maximum $\left(T_{\max }\right)$ temperature of production, light saturation of production $\left(D_{j}\right)$, maximum production rate $\left(P_{\max }\right)$, sinking rate $\left(s_{j}\right)$, half-saturation constants $\left(K_{p, j}\right)$ for phosphorus $(\mathrm{P})$ and nitrogen $(\mathrm{N})$, non-predatory mortality rate $\left(m_{j}\right)$, and metabolic costs of production $\left(R_{j}\right)$. 
TABLE 2. Group-specific model input parameters for consumer groups.

\begin{tabular}{|c|c|c|c|c|c|c|c|c|c|c|c|}
\hline Functional groups & $\begin{array}{c}B_{0} \\
\left(\mathrm{~g} \mathrm{C} / \mathrm{m}^{3}\right)\end{array}$ & $\begin{array}{l}T_{\mathrm{opt}} \\
\left({ }^{\circ} \mathrm{C}\right)\end{array}$ & $\begin{array}{l}T_{\max } \\
\left({ }^{\circ} \mathrm{C}\right)\end{array}$ & $\begin{array}{c}C_{\max } \\
\left(\mathrm{g} \mathrm{C}^{-\mathrm{g}}\right. \\
\left.\mathrm{C}^{-1} \cdot \mathrm{d}^{-1}\right)\end{array}$ & $\begin{array}{l}\text { SDA } \\
\left(d^{-1}\right)\end{array}$ & $\begin{array}{l}T_{\text {resp }} \\
\left({ }^{\circ} \mathrm{C}\right)\end{array}$ & $\begin{array}{c}R_{\max } \\
(\mathrm{g} \mathrm{C} \cdot \mathrm{g} \\
\left.\mathrm{C}^{-1} \cdot \mathrm{d}^{-1}\right)\end{array}$ & $\begin{array}{c}R_{\text {prd }} \\
\left(\mathrm{d}^{-1}\right)\end{array}$ & $\begin{array}{c}U \\
\left(\mathrm{~d}^{-1}\right)\end{array}$ & $\begin{array}{c}m \\
\left(\mathrm{~d}^{-1}\right)\end{array}$ & $\begin{array}{l}\text { Threshold } \\
\left(\mathrm{g} \mathrm{C} / \mathrm{m}^{3}\right)\end{array}$ \\
\hline \multicolumn{12}{|l|}{ Zooplankton } \\
\hline Mesozooplankton & $8.00 \times 10^{-4}$ & 11 & 15 & 1.6 & 0.16 & 47 & 3.00 & 0.1 & 0.02 & 0.001 & \\
\hline Microzooplankton & $1.20 \times 10^{-5}$ & 25 & 42 & 1.5 & 0 & 28 & 0.30 & 0 & 0.02 & 0.01 & \\
\hline HNAN & $4.00 \times 10^{-3}$ & 25 & 40 & 1.3 & 0 & 40 & 0.78 & 0 & 0.04 & 0.05 & \\
\hline \multicolumn{12}{|l|}{ Gelatinous zooplankton } \\
\hline Mnemiopsis leidyi & $5.40 \times 10^{-4}$ & 22 & 37 & 0.6 & 0 & 31 & 0.15 & 0.005 & 0.041 & 0.03 & \\
\hline Chrysaora quinquecirrha & $1.00 \times 10^{-9}$ & 22 & 30 & 0.9 & 0 & 30 & 0.1 & 0 & 0.04 & 0.05 & \\
\hline \multicolumn{12}{|l|}{ Pelagic omnivorous fish } \\
\hline Brevoortia tyrannus & $7.30 \times 10^{-2}$ & 28 & 36 & 1.3 & 0.17 & 33 & 0.002 & 0.005 & 0.1 & 0.005 & $5.00 \times 10^{-1}$ \\
\hline Anchoa mitchilli & $3.00 \times 10^{-2}$ & 27 & 35 & 0.41 & 0.10 & 30 & 0.018 & 0.005 & 0.15 & 0.006 & $6.00 \times 10^{-2}$ \\
\hline \multicolumn{12}{|l|}{ Benthic invertebrates } \\
\hline On-reef invertebrates & $5.00 \times 10^{-2}$ & 30 & 50 & 0.08 & 0 & 45 & 0.08 & 0 & 0.3 & 0.001 & \\
\hline Off-reef invertebrates & $7.40 \times 10^{-1}$ & 30 & 50 & 0.08 & 0 & 45 & 0.08 & 0 & 0.3 & 0.001 & \\
\hline Crassostrea virginica & $4.10 \times 10^{-2}$ & 27 & 34 & 0.55 & 0.2 & 27 & 0.015 & 0.015 & 0.015 & 0.001 & \\
\hline \multicolumn{12}{|l|}{ Benthic fish } \\
\hline Reef-associated fish & $1.30 \times 10^{-2}$ & 27 & 34 & 0.15 & 0.1 & 29 & 0.034 & 0.001 & 0.1 & 0.002 & $3.60 \times 10^{-2}$ \\
\hline Nonreef fish & $5.40 \times 10^{-3}$ & 27 & 34 & 0.3 & 0.1 & 29 & 0.03 & 0 & 0.06 & 0.001 & $1.20 \times 10^{-2}$ \\
\hline \multicolumn{12}{|l|}{ Larval pools } \\
\hline M. leidyi larvae & 0 & 25 & 35 & 0.7 & 0 & 25 & 0 & 0 & 0.025 & 0.07 & \\
\hline A. mitchilii larvae & 0 & 25 & 35 & 0.7 & 0 & 25 & 0 & 0 & 0.025 & 0.05 & \\
\hline C. virginica larvae & 0 & 25 & 35 & 0.7 & 0 & 25 & 0 & 0 & 0.025 & 0.1 & \\
\hline
\end{tabular}

Notes: The parameters are initial values of group biomass $\left(B_{0}\right)$, optimal $\left(T_{\mathrm{opt}}\right)$ and maximal $\left(T_{\max }\right)$ temperature of consumption, maximum consumption rate $\left(C_{\max }\right)$, metabolic costs of consumption (SDA), optimal temperature of respiration $\left(T_{\text {resp }}\right)$, maximum respiration rate $\left(R_{\max }\right)$, metabolic costs of producing reproductive tissue (e.g., egg biomass, $\left.R_{\text {prd }}\right)$, loses to excretion $(U)$, nonpredatory mortality $(m)$, and the forage fish surplus production threshold. The abbreviation HNAN stands for heterotrophic nanoflagellates.

Bay Monitoring Program [CBMP]; Stations LE1.1, ET5.2; data available online). ${ }^{7}$

The zooplankton category included two functional groups intended to represent meso- $(\geq 200 \mu \mathrm{m}$, e.g., Acartia tonsa) and micro- $(<200 \mu \mathrm{m}$, e.g., rotifers, nauplii) zooplankton (Kimmel and Roman 2004). Meso- and microzooplankton groups were linked by a naupliar production term $\left(\mathrm{Rp}_{i}\right.$; Eq. 2) and a naupliar maturation term (5\% microzooplankton biomass/d; model day 100-270). Gelatinous zooplankton were divided into two functional groups: ctenophores (Mnemiopsis leidyi) and scyphomedusan jellyfish (Chrysaora quinquecirrha). Both species are important pelagic consumers in summer (Purcell et al. 1994b).

Pelagic forage fish were represented by two functional groups: zooplanktivores (Anchoa mitchilli) and suspension feeding herbivores (Brevoortia tyrannus). Anchoa mitchilli are the most abundant prey fish in the Bay (Jung and Houde 2004). Monthly mean biomass for A. mitchilli was based on data collected in 1995 and 2000 in the mainstem Chesapeake Bay (Wang and Houde 1994, 1995, Jung and Houde 2004) and in 2004 in the Patuxent River (Miller 2004). Seasonal movement of anchovy in and out of the system was simulated by adjusting the production surplus term to reflect a higher observed

\footnotetext{
${ }^{7}\langle$ http://www.chesapeakebay.net/dataandtools.aspx $\rangle$
}

biomass in the late summer and fall. There are little biomass data for B. tyrannus in Chesapeake Bay and so we used an annual mean biomass of $0.145 \mathrm{~g}$ menhaden $\mathrm{C} /$ $\mathrm{m}^{3}$ based on estimates of $1.07 \mathrm{~g}$ wet mass $/ \mathrm{m}^{3}$ from analyses conducted by the Atlantic States Marine Fisheries Commission (ASMFC, J. Uphoff, unpublished data). Seasonal migration of forage fishes was modeled through adjustments to functional group biomass. Because a large fraction of the B. tyrannus population immigrates into the Bay in the spring and emigrates out in the fall, we set initial (1 January) biomass as one-half of the annual mean biomass and allowed summer maximum biomass to reach threefold the annual mean. This approach simulated the trophic effects of seasonal migration patterns without modeling migration explicitly.

Benthic consumers in the model were separated into two ecological categories: benthic invertebrates and benthic omnivorous fishes. Benthic invertebrates were separated into three functional groups: eastern oysters that live in dense aggregations termed oyster reefs, other invertebrates associated with oyster reefs, and off-reef invertebrates. Benthic omnivorous fishes were separated functionally into species that are residents of oyster reefs and those that are not. Fishes that are reef transients were accommodated in the model by including prey items on oyster reefs in the diet of both functional groups. The mean biomass of $C$. virginica was obtained 
from the Chesapeake Bay Oyster Population Estimation (CBOPE) project (data available online). ${ }^{8}$

Other invertebrates in the model were separated into on-oyster-reef and off-oyster-reef groups to differentiate between those associated and not associated with reefs. Both groups were modeled to represent a mix of suspension-feeders, deposit feeders, and carnivores. The diet of each composite group was partitioned based on Hagy (2002); the on-reef assemblage was assumed to be trophically equivalent to the off-reef assemblage. Biomass for the on-reef group was calculated as a fixed proportion of oyster biomass per unit area, and was based on data comparing the biomass of oysters to the biomass of other reef invertebrates on experimental reefs in Virginia (Luckenbach et al. 2005). The target for onreef invertebrate summer biomass was 4.5 times oyster biomass in the model.

Reef resident fishes were based on data for Gobiosoma bosc, which is the most abundant reef resident fish in mesohaline Chesapeake Bay (Breitburg et al. 1995). Biomass estimates for $G$. bosc were based on the relationship for reef fish biomass in the summer being 1.9 times oyster biomass (Abbe 1992, Breitburg et al. 1995, Harding and Mann 1999). Demersal non-reef and reef-transient fishes were described using the energetics of spot (Leiostomus xanthurus, Moser and Hettler 1989), an abundant demersal, benthic-feeding fish in Chesapeake Bay (Wang and Houde 1995, Murdy et al. 1997). Initial biomass of non-reef demersal fishes was set to $18 \%$ of $A$. mitchilli biomass based on simultaneous Baywide estimates of biomass for both demersal fish species and A. mitchilli (Jung 2002). The relationship between the target biomass for non-reef demersal fishes and $A$. mitchilli was used only to set initial biomass and no special relationship between these two groups existed in model simulations.

Production surplus for forage fish.-Top piscivores were not included as a trophic group in the TroSim model in order to maintain a focus on the middle and bottom of the food web, and to eliminate the need to explicitly model other sources of mortality such as fishing. However, we predicted potential effects of the modeled food web on top piscivores indirectly by estimating the change in their forage base through the use of a "production surplus" term based on fish groups explicitly included in the model. A production threshold was defined for each fish functional group (Table 2) in the model based on maximum biomass from field data. At the end of each model day, the amount of biomass present in the model for each forage fish group was compared to this group-specific threshold and if biomass exceeded that threshold, biomass was reduced to the threshold and the surplus was removed from the model simulation. Changes in this production surplus can be used as a comparative tool for estimating the effect of

\footnotetext{
${ }^{8}\langle$ www.vims.edu/mollusc/cbope/index.htm $\rangle$
}

food web manipulations on prey available to top piscivores. The use of a production threshold to simulate top-down control assumes the influences of higher level predators on pelagic prey fish is related to prey fish biomass and as such will be influenced by oyster restoration. The model does not allow for any compensatory changes in prey selection by piscivores, so it cannot be used to directly examine the influence of differences in prey preferences among top piscivores on model predictions. This constraint was a necessary simplification of the model.

Detritus pools.-Particulate organic carbon (POC) was included in the model as two distinct pools: water column POC and sediment POC. Contributions to the POC pools came from consumer waste production and non-predatory mortality of functional groups. Losses from the POC pools were consumption by detrital feeders, microbially mediated breakdown of POC into dissolved organic carbon (DOC), and particle burial. The two POC pools were linked by sinking and resuspension dynamics.

The contribution to the water column POC pool from non-predatory mortality of fishes was limited to $50 \%$ of daily non-predatory mortality within each trophic group based on the assumption that most large animals require more time to decompose into POC and in that time a significant fraction of this dead biomass will be lost to the system through flushing out of the mesohaline areas, washing up on shore, or consumption by groups not considered in this model (e.g., avian and benthic scavengers).

Particle sinking rates, measured as the proportion transferred out of the water column per unit time, varied depending on type. Phytoplankton was modeled to sink out of the water column using a cell size-dependent sinking rate (Table 1). Fecal material was assumed to sink from the water column POC pool in only one day (Beaulieu 2003, Giles and Pilditch 2004, North et al. 2004). For other forms of POC, loss from the water column POC pool due to sinking was $60 \%$ per day.

Based on physical processes at the sediment interface (Giles and Pilditch 2004, North et al. 2004) the resuspension rate of particles was specified as $50 \%$ per day of the available sediment POC. Fecal material was not considered available for resuspension based on reported rapid sinking rates for bivalve fecal pellets (Giles and Pilditch 2004) and their rapid incorporation into surface sediments (Holyoke 2008). All other POC was considered available for both consumption and resuspension for a period of 10 days from its introduction into the sediment POC pool. POC was lost to the system after 10 days based on an adaptation of the inverse efolding model for sediment burial used by North et al. (2004). This approach was adapted for a difference model and to account for multiple transport components (e.g., flushing and burial) in a single loss term.

Nutrient pools.-The daily mean concentrations (mg/ $\mathrm{L})$ of nitrogen $(\mathrm{N})$ and phosphorus $(\mathrm{P})$ were input 
parameters based on CBMP data for the mesohaline portion of the Bay, and were included to set potential limits to primary production. Monthly mean data (1993-2003) were converted to a daily trend by random draws from a normal distribution of nutrient concentration with the month-specific mean and variance.

Data for water temperature, total inorganic suspended solids (TISS) and irradiance levels at the water surface were obtained from CBMP data (1993-2003) and input into the model on a daily basis. Total suspended solids data from the CBMP database include organic particles and phytoplankton; data were adjusted to remove these components. Daily trends for all parameters were calculated as described for nutrients.

Three larval sub-pools were included to deal with one of two situations: larvae represent an important prey item (e.g., A. mitchilli and C. virginica) or the seasonal biomass trend of the adult group was dominated by recruitment (e.g., M. leidyi). Larval sub-pools all began on model day one with no biomass, and reproductive material was added to the pool during a period appropriate to each group. Larvae consumed prey in the model according to their bioenergetic needs. Mortality $\left(m_{i}, \mathrm{~d}^{-1}\right)$ was calculated and removed daily, but growth $\left(G\right.$, period $\left.^{-1}\right)$ occurred in a stair-step fashion at the beginning (G1, egg to larval growth) and end $(\mathrm{G} 2$, larval to adult growth) of the larval period. The length of the larval period was defined for each larval sub-pool based on data describing the period when respective larvae are present in Chesapeake Bay (Purcell et al. 1994a, Kennedy 1996, Grove and Breitburg 2005). Larval biomass was transferred to the adult pool within a year for M. leidyi. Because A. mitchilli and C. virginica have a maturation period from larvae to reproductive adults that extended beyond single year model simulations, larval biomass from these two groups was not added to the reproductively mature adult pool.

\section{Consumer diet}

Consumer diet was modeled based on relative prey biomass and a set of consumer- and prey-specific preference parameters. The use of a preference term rather than fixed diet proportions allowed the consumer diet to adjust to fit relative abundance of prey. The measure of prey preference used in this model was Ivlev's electivity index adjusted to vary between 0 and 1 (Paloheimo 1979). Prey preference for each functional group was based on literature data (Appendix A). In cases where a functional group represented a broad taxonomic assemblage (e.g., benthic invertebrates) the diet was determined based on the relative proportion of various trophic groups within the larger functional group.

Carbon gain from ingested diet was also affected by assimilation efficiency and handling efficiency terms that were consumer- and prey-specific. Assimilation efficiency included a term that was loss of carbon to the fecal pool (see Methods: Functional groups: Detritus pools) and handling efficiency was a loss term back to the living prey pool. The handling efficiency term allowed for dynamics such as "sloppy feeding" in ctenophores and mesozooplankton.

\section{Model testing and simulations}

The current analysis was based on data from the mesohaline portions of two Chesapeake Bay tributaries (Patuxent and Choptank Rivers). Individual simulations represented a single year and considered the trophic impact of oyster restoration on the seasonal dynamics of production and biomass for each functional group, as well as on the total spring (March-June) and summer (July-September) production for each functional group. Predictions of the fully parameterized model were compared to long-term (1993-2003) abundances and seasonal trends in functional group biomass calculated from field data. Minor adjustments were made to model parameters within the bounds of natural variability, which reduced the magnitude of differences between baseline model predictions and field data. When this was not possible, we sought to understand why the differences occurred and how they might affect model predictions.

The fully parameterized model was used to predict effects on the Chesapeake Bay food web of increased oyster biomass resulting from restoration. We conducted simulations at "current" (1994) levels of oyster biomass and 10, 25, and 50 times current oyster biomass. The restoration target for Chesapeake Bay established in the Chesapeake Bay 2000 agreement (Environmental Protection Agency 2000) is 10 times current biomass. Eastern oyster abundances were estimated by Newell (1988) to be about $1 \%$ of the abundances present prior to major exploitation. Since the mid 1980s, eastern oyster stocks have continued to decline. Thus, although these simulated populations may seem large, they do not come close to historic oyster stocks. This model analysis addresses effects of oyster restoration in the tributaries of Chesapeake Bay, which are the most likely sites of oyster restoration in the Chesapeake Bay ecosystem. Simulations also have been conducted representing the mainstem of the Bay; whereas these simulations are not discussed here, the results are available for comparison in Appendix C.

Simulated increases in oyster biomass depend on several key assumptions. First, increases in oyster biomass were assumed to represent increases in oyster density on existing oyster reefs rather than an expansion of current reef area. As oyster biomass increased in the model, we therefore modeled a proportionate increase in reef-associated benthic invertebrates, but no change in soft-bottom (non-reef-associated) invertebrates. We assumed a positive linear relationship between oyster biomass and biomass of reef resident fishes. We also assumed a positive threshold between increases in oyster biomass and increases in C. quinquecirrha biomass based on data indicating a precipitous decline in C. quinquecir- 
rha associated with the late 1980s decline in Maryland oyster landings (Breitburg and Fulford 2006). Any increase in oyster biomass $\geq 10$-fold included up to a 20 fold increase in the maximum summer biomass for $C$. quinquecirrha. This increase was modeled as an increase in the density of sea nettle polyps (the life stage thought to benefit from increased oyster density), but the realized effect of this increase on biomass of sea nettle medusae (the life stage that is an important consumer in the Chesapeake Bay food web) varied as a function of other trophic interactions. A sensitivity analysis of model output to these assumptions was conducted by running the model with each assumption present and removed at 25 times current oyster biomass. The metric of sensitivity was the proportional change in functional group seasonal production to an increase in oyster biomass with an assumption removed from the model. For instance, if a functional group's summer production was reduced by $20 \%$ in the full model, but reduced by only $15 \%$ with an assumption removed, then the removal of the assumption proportionally reduced the influence of oyster restoration on this functional group by 0.25 .

Model results for the various oyster restoration scenarios were compared to model results predicting the effect of a $50 \%$ reduction in nutrient loadings from 1994 levels. For nutrient-reduction model simulations, nutrient concentrations and phytoplankton biomass were reduced to reflect a $50 \%$ reduction in nutrient load and the associated decline in phytoplankton biomass predicted by the Chesapeake Bay Water Quality Model (Cerco and Noel 2005). Water quality model outputs served as model input for TroSim, which simulated the effects of phytoplankton reduction on consumers.

There is also some evidence that a $50 \%$ reduction in nutrient load into the Bay and its tributaries will result in a decrease in benthic habitat impacted by hypoxia (Hagy 2002, Testa et al. 2008). There is interannual variation in the bottom area affected by hypoxia; in a year of severe hypoxia, a seasonal maximum of about $18 \%$ of the bottom in the mainstem Bay and mesohaline portions of tributaries, combined, is overlain by water $<3 \mathrm{mg} \mathrm{O}_{2} / \mathrm{L}$. Chesapeake Bay tributaries vary in the severity and spatial extent of hypoxia, ranging from no or minimal hypoxia (e.g., the Choptank River) to as much as $40 \%$ (Patuxent) to $60 \%$ (Potomac) of the bottom area in mesohaline waters in a severe year (Chesapeake Bay Program, unpublished data). In order to examine the potential trophic effects of a reduction in bottom-water hypoxia we ran reduced nutrient load simulations with and without a hypothesized increase (13\% based on Hagy 2002) in bottom area that would become suitable benthic habitat due to an increase in bottom layer dissolved oxygen levels.

\section{Results}

Model validation

The fully parameterized model produced a reasonable fit to available seasonal biomass trends for most functional groups (Appendix B). Model predictions of functional group monthly mean biomass were within two standard deviations of the observed monthly mean biomass with two exceptions. Poorest fits between baseline model predictions and field data were for microzooplankton and off-reef benthic invertebrates. Copepod nauplii dominate the microzooplankton biomass in the tributaries from March through April and from July through September. The observed deviations between predicted and observed microzooplankton biomass occurred in February and May and are likely the result of overestimation of nauplii production for spring dominant mesozooplankton (i.e., Eurytemora affinis) in the model. The influence of model overestimation of microzooplankton biomass at the beginning and end of the spring period is unlikely to affect model predictions during the primary period of oyster influence in the summer. Baseline simulations overestimated offreef benthic invertebrate biomass during late spring through fall. This was expected as the model simulates an un-stratified water column and excludes seasonal mortality of benthos due to hypoxia, which occurs in the Patuxent but not the Choptank River. More explicit incorporation of hypoxic effects in future modeling efforts may improve predictions of seasonal patterns of benthic invertebrate biomass but this change will have minimal effects on our current comparison of pelagic production.

\section{Effects of oyster restoration}

Light penetration and TISS.--Increasing oyster biomass decreased light attenuation (increased light penetration), with largest effects projected from June through September (Fig. 2a, Table 3). This largely results from projected declines in mean TISS concentration from June to September. The oyster-mediated reduction of particle concentration and light attenuation also began earlier for 25- (day 141) and 50-fold (day 111) increases resulting in a lengthening of the overall period of effect as oyster biomass increases.

Primary production.-Simulations indicated that increasing oyster biomass by 10 - to 50-fold would decrease spring and summer total production (TP; spring, ordinal day 80-170; summer, ordinal day 171260) of phytoplankton summed across phytoplankton size classes, but that the effects would vary among individual size classes (Fig. 3a, c, Table 3). However, an increase in TP was indicated for $<2-\mu \mathrm{m}$ picoplankton in summer, the size class least vulnerable to oyster filtration. All other size classes experienced either minimal change (i.e., $<5 \%$ ) or a decrease in TP in both spring and summer across all levels of oyster biomass tested (Fig. 3a, c). The 4-10 and 2-4 $\mu \mathrm{m}$ size classes experienced largest declines, with decreases in the 4-10 $\mu \mathrm{m}$ size class having the most effect on overall phytoplankton production due to the larger amount of overall biomass in this category (30-40\%). In general, 

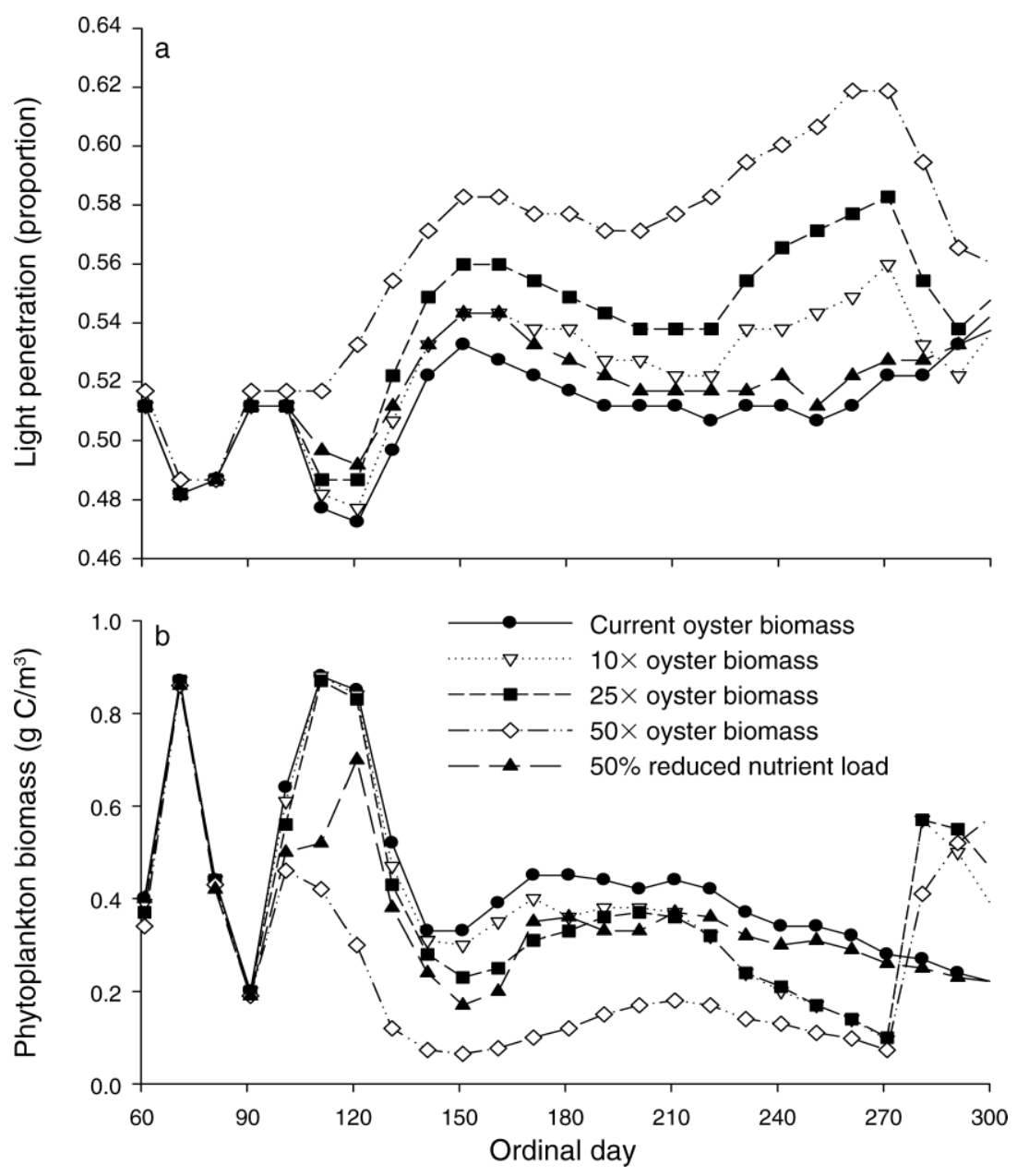

FIG. 2. Predicted seasonal trend in (a) light penetration and (b) phytoplankton biomass at four different levels of oyster biomass restoration or a $50 \%$ reduction in nutrient load. Light penetration is measured as the proportion of surface light reaching a depth of $1 \mathrm{~m}$.

oysters had the largest effect in the model on phytoplankton between 2 and $50 \mu \mathrm{m}$ ESD.

Predicted effects of increased oyster biomass on phytoplankton biomass were similar to predicted effects on phytoplankton production (Table 3). Maximum phytoplankton biomass occurred in model simulations from April to mid May (Fig. 2b). Increasing oyster biomass decreased spring phytoplankton biomass by $11 \%$ or less at 10 - and 25 -fold increase in oyster biomass, but reduction was $53 \%$ at 50 -fold. Annual mean biomass was reduced 5, 8, and $23 \%$. Oysters had an increased period of effect for a 50 -fold increase that resulted in decreased phytoplankton biomass between April and August.

Consumer production.-Effects of increasing oyster biomass on pelagic consumer production was more consistently negative than the effects on production of phytoplankton (Fig. 3b, d, Table 3). The only exception to this observation was sea nettles, which had a positive association with the low and moderate increases in oyster biomass related to the positive habitat effects of more oyster reef on the polyp stage included in the model (Breitburg and Fulford 2006). Changes in daily production for particular consumer groups in response to increasing oyster biomass were most evident at times of peak consumer biomass (Figs. 2 and 4).

Total production for microzooplankton and mesozooplankton in model simulations decreased dramatically in response to increasing oyster biomass in the summer (Fig. 3b, d, Table 3), especially at 25- and 50fold increases in oyster biomass. Predicted reductions in the spring were negligible except at a 50 -fold increase in oyster biomass, which is related to the grazing effect of oysters reaching meaningful levels earlier in the year at the highest simulated biomass. The effect on zooplankton was quite large; predominantly due to the high diet overlap between oysters and mesozooplankton, strong interactions between meso- and microzooplankton, and the ability of oysters to remove far more phytoplankton from the water column than they require for mainte- 
TABLE 3. Summary of model-predicted effect of three levels of oyster restoration on total production and biomass of all functional groups included in the model in simulations of the mesohaline section of a representative Chesapeake Bay tributary.

\begin{tabular}{|c|c|c|c|c|c|c|c|c|}
\hline \multirow[b]{3}{*}{ Measure } & \multicolumn{4}{|c|}{ Spring (ordinal days $80-170$ ) } & \multicolumn{4}{|c|}{ Summer (ordinal days 171-260) } \\
\hline & \multicolumn{3}{|c|}{ Increase in oysters } & \multirow{2}{*}{$\begin{array}{l}50 \% \text { nutrient } \\
\text { reduction }\end{array}$} & \multicolumn{3}{|c|}{ Increase in oysters } & \multirow{2}{*}{$\begin{array}{l}50 \% \text { nutrient } \\
\text { reduction }\end{array}$} \\
\hline & $10 \times$ & $25 \times$ & $50 \times$ & & $10 \times$ & $25 \times$ & $50 \times$ & \\
\hline \multicolumn{9}{|l|}{ Total production } \\
\hline Phytoplankton & -3 & -6 & -43 & -23 & -17 & -25 & -67 & -25 \\
\hline Mesozooplankton & -0.5 & -0.9 & -1 & -6.5 & -95 & -81 & -100 & -12 \\
\hline Microzooplankton & -1 & -3 & -59 & -1 & -71 & -89 & -100 & -10 \\
\hline M. leidyi & 59 & 62 & -76 & -41 & -13 & -28 & -94 & -16 \\
\hline C. quinquecirrha $\dagger$ & 1400 & 1400 & 1400 & 0 & 46 & 17 & -83 & -13 \\
\hline A. mitchilli & 0 & 0 & -71 & 0 & -75 & -95 & -100 & -1 \\
\hline B. tyrannus & -5 & -9 & -28 & -9 & -10 & -18 & -41 & -10 \\
\hline \multicolumn{9}{|l|}{ Biomass/concentration } \\
\hline Light penetration & 0.6 & 1.5 & 3.5 & 1.0 & 2 & 4 & 7 & 0.8 \\
\hline TISS & -0.7 & -2.2 & -5.2 & 0.0 & -4.9 & -12.6 & -25.3 & 0.0 \\
\hline Suspended POC & -10 & -21 & -42 & -14 & -24 & -37 & -54 & -9 \\
\hline Phytoplankton & -4 & -11 & -53 & -28 & -26 & -30 & -66 & -17 \\
\hline Mesozooplankton & 0 & 0 & 1 & 0 & -87 & -96 & -100 & -11 \\
\hline Microzooplankton & -2 & -9 & -42 & -2 & -82 & -95 & -100 & -5 \\
\hline M. leidyi & 2 & 2 & -72 & -8 & -86 & -88 & -98 & -20 \\
\hline C. quinquecirrhat & 559800 & 559800 & 197100 & 0 & 297 & 156 & -42 & -11 \\
\hline A. mitchilli & -0.1 & -0.5 & -26 & 0 & -48 & -60 & -89 & -1 \\
\hline B. tyrannus & -0.1 & -0.4 & -1 & -0.3 & -0.3 & -0.5 & -1.4 & -0.3 \\
\hline Benthic fishes $\uparrow$, & 558 & 1473 & 2998 & 0 & 56 & 218 & 343 & -0.4 \\
\hline
\end{tabular}

Notes: All values are given as percentage change from baseline seasonal predictions with 1994 levels of oyster biomass. Biomass change for forage fish includes reductions in the surplus production term. The very large increase in spring production and biomass of sea nettles in increased oyster scenarios reflects earlier production of ephyra in these simulations to allow sea nettle peak abundances to reflect increased habitat provided by oysters. Abbreviations are: TISS, total inorganic suspended solids; P, particulate organic carbon.

$\dagger$ Production and biomass change includes adjustments related to assumptions about influence of increased oyster biomass on this functional group.

$\$$ Production and biomass change includes adjustments related to assumptions about influence of reduced nutrient loading on this functional group via decreases in seasonal hypoxia.

nance and growth. These important predictions, which were projected up the food web, are addressed in detail in Discussion.

Gelatinous zooplankton production was predicted to have a mixed response to increases in oyster biomass as a result of the combined effects of the assumption of increased benthic habitat for the $C$. quinquecirrha polyp stage and the trophic effects of oysters reducing the zooplankton food source for ctenophores (M. leidyi), which are the main food source for $C$. quinquecirrha. Spring TP of $M$. leidyi was predicted to increase in response to a 10 - and 25 -fold increase in oyster biomass but decrease in response to a 50-fold increase (Fig. $3 \mathrm{~b}, \mathrm{~d}$, Table 3). Because spring production for both gelatinous zooplankton groups was low, these increases had little effect on biomass. Summer TP of M. leidyi decreased with increasing oyster biomass in model simulations due to the influence of reduced zooplankton production and increased predation from $C$. quinquecirrha.

Chrysaora quinquecirrha was allowed to increase as much as 20-fold from its current maximum summer biomass and as a result had a large increase in total spring-summer production, especially at a 10-fold increase in oyster biomass (Fig. 3b, d, Table 3). Spring TP for $C$. quinquecirrha increased uniformly for all increases in oyster biomass. Summer TP was predicted to increase for a 10- and 25-fold increase in oyster biomass, but decrease in response to a 50 -fold increase in oysters. At the highest simulated oyster biomass increase, polyp production was counterbalanced by decreases in medusoid production resulting from reduced biomass of zooplankton and ctenophore prey. In general, the model predicted a trade-off between ctenophore and sea nettle biomass that resulted in lower than expected changes in biomass of gelatinous zooplankton.

Simulations generally yielded negative effects of increased oyster biomass on TP of forage fishes, but the magnitude of the response differed between the two fish functional groups in the model (Fig. 3b, d, Table 3). Spring TP for B. tyrannus was more strongly affected by oysters than $A$. mitchilli at 10 - and 25-fold increases, but TP declined greatly for $A$. mitchilli at 50-fold. Summer TP for B. tyrannus was lower but followed a similar trend to that observed in the spring, but summer TP for A. mitchilli was predicted to decrease $75-100 \%$ across the three levels of oyster biomass. Large predicted declines in A. mitchilli production are likely overestimated, but this prediction stems from the negative influence of oysters on zooplankton and the dependence 

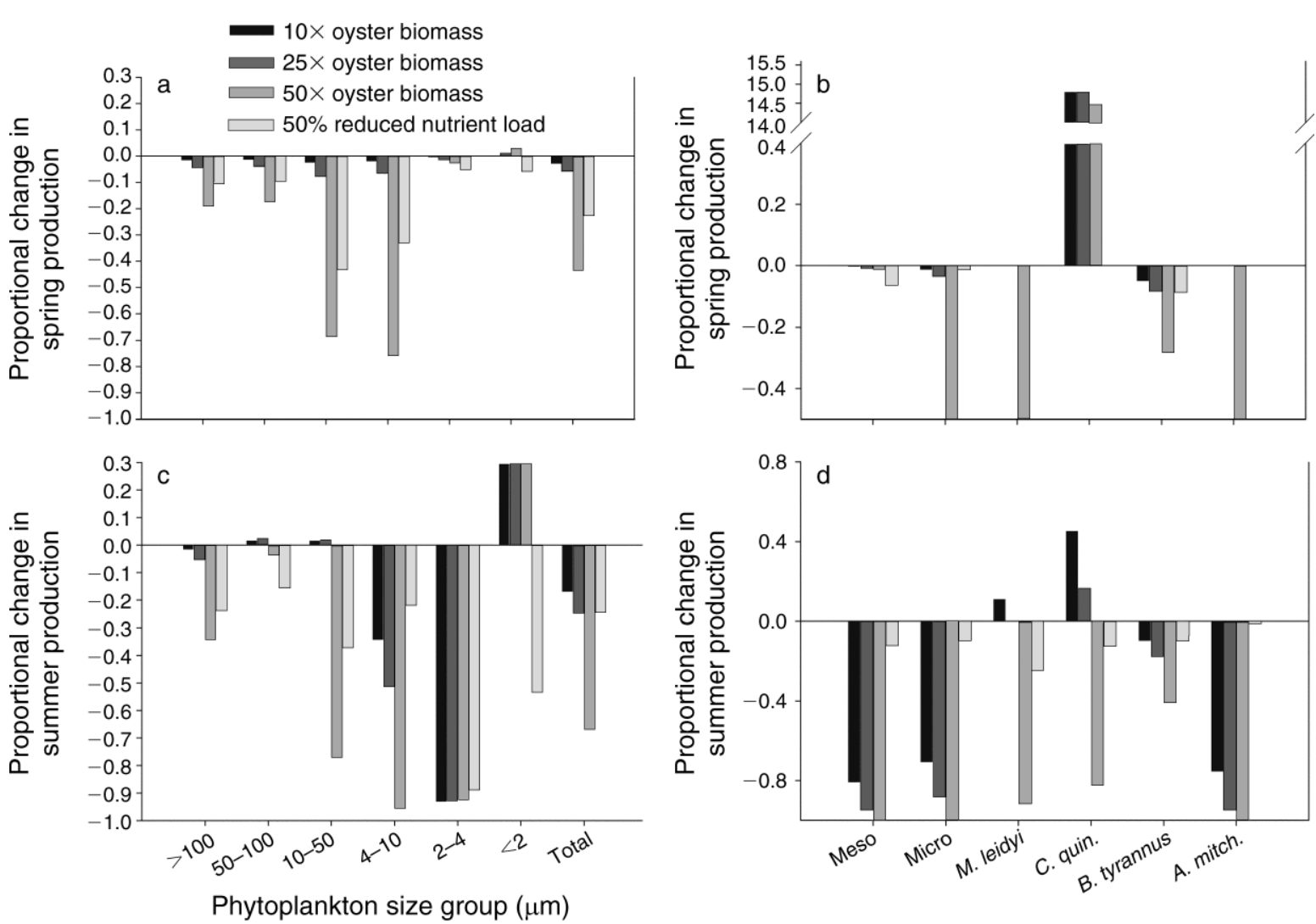

FIG. 3. Predicted proportional change in total production in response to three levels of increase in oyster biomass or a $50 \%$ reduction in total nutrient load for $(a, c)$ phytoplankton and $(b, d)$ consumer functional groups in $(a, b)$ spring and (c, d) summer. Phytoplankton data are given by size class and for a biomass-weighted total across all size classes. Data are the proportional change from predicted total production under 1994 conditions. Abbreviations are: Meso, mesozooplankton; Micro, microzooplankton; $M$. leidyi, Mnemiopsis leidyi; C. quin., Chrysaora quinquecirrha; B. tyrannus; Brevoortia tyrannus; A. mitch., Anchoa mitchilli.

of zooplanktivorous fishes on pelagic zooplankton production.

Daily production surplus (i.e., exported to simulate apical consumption) for all forage fish groups was reduced by increases in oyster biomass but the magnitude of effect differed by fish functional group in a manner similar to overall production. Daily production surplus for B. tyrannus was reduced by 6,13 , and $35 \%$ and $A$. mitchilli experienced high percentage surplus production removal at all levels of oyster biomass increase. Benthic fish daily surplus increased $125 \%$ for a 10-fold increase in oyster biomass and then declined by $61 \%$ for both a $25-$ and 50 -fold increase. This initial increase in benthic fish production was a result of the large increase in absolute reef fish biomass in the model which was sufficient to compensate for reduced specific production at a 10 -fold increase in oyster biomass, but not at 25- or 50-fold.

Consumer biomass.-Simulations predicted that increasing oyster biomass would strongly affect biomass of meso-, micro-, and gelatinous zooplankton, and would have varying effects on biomass of the forage fish groups. Mean spring mesozooplankton biomass did not change with increasing oyster biomass, but decreased $80-100 \%$ in the summer (Fig. 4, Table 3). Microzooplankton biomass decreased less than $10 \%$ in the spring in response to a 10 - or 25 -fold increase in oysters but the decline quadrupled at 50 -fold (Fig. 4, Table 3). This again suggests that the impact of oysters occurs earlier in the year at higher biomass.

Summer mean biomass of $M$. leidyi decreased by $86-$ $98 \%$ in response to both the bottom-up effects of reduced zooplankton biomass and the top-down effects of predation by the modeled increase in sea nettle biomass (Table 3$)$. The large $(\sim 13 \times)$ increase in $C$. quinquecirrha peak summer biomass resulting from increased polyp habitat observed at a 10 -fold increase in oyster biomass was not sustained at larger increases in oyster biomass and was similar to predicted effects on $C$. quinquecirrha production.

There were no effects of oyster biomass increases on B. tyrannus biomass (Fig. 4, Table 3) as the observed reduction in summer production was small and largely influenced surplus production. Daily mean biomass of A. mitchilli decreased by $55-80 \%$ as a direct result of predicted declines in the two zooplankton pools (Fig. 4). 

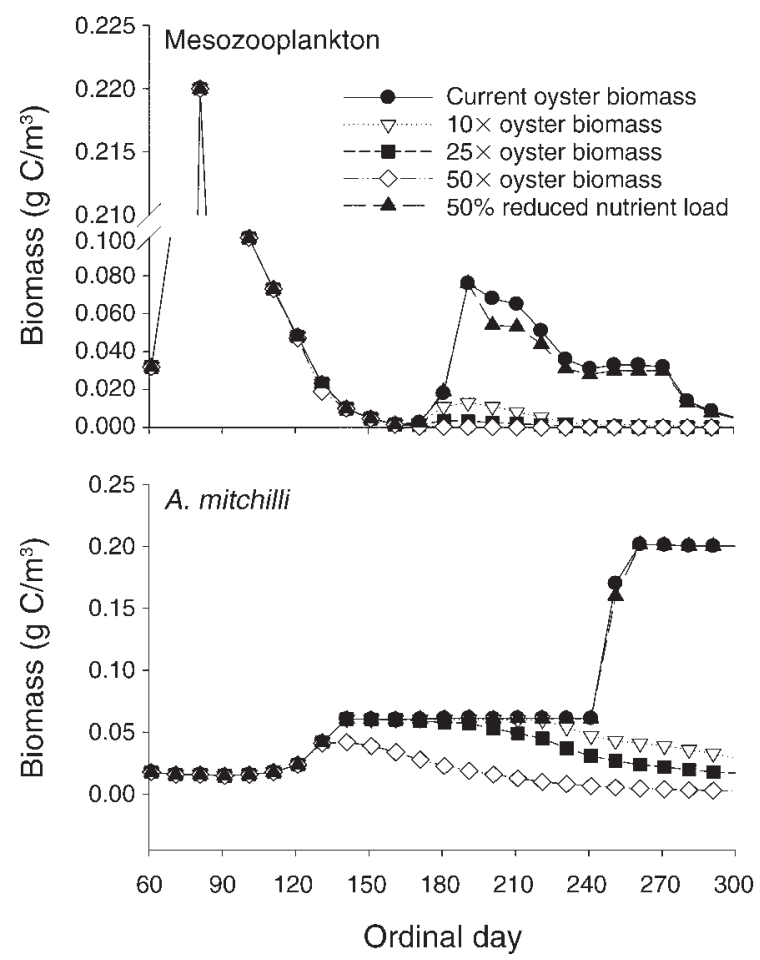
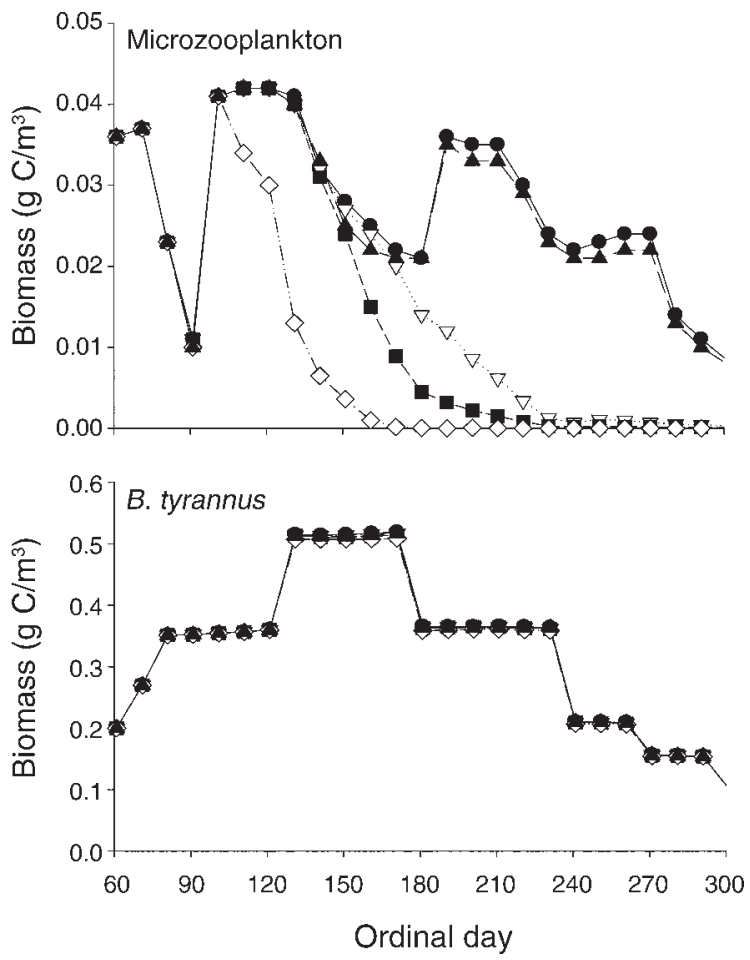

FIG. 4. Predicted seasonal trend in pelagic consumer biomass at four levels of oyster biomass increase or a $50 \%$ reduction in nutrient load. Data are given separately for mesozooplankton, microzooplankton, zooplanktivorous fishes, and filter-feeding fishes.

Benthic fish summer biomass was increased by $56-343 \%$ in response to increased oyster biomass as a result of a modeled increase in the abundance of reef-associated fishes and on-reef invertebrate prey. Observed increases in benthic fish production, particularly at a 50-fold increase in oyster biomass were likely overestimated as the influence of summer hypoxia is not included in the model and the relationship between oyster and reef fish biomass may not be linear. An increase in benthic fish biomass is, nevertheless, anticipated in response to an increase in oyster biomass.

\section{Comparison of oyster restoration and nutrient reduction}

Predicted effects of nutrient reduction on production and biomass of phytoplankton and various consumers differed both qualitatively and quantitatively from effects of increases in oyster biomass. Production of phytoplankton and all consumer groups declined under the modeled nutrient reduction scenario. Declines in phytoplankton production were more consistent across size categories (Fig. 3a, c), and declines in production of both producer and consumer groups were more consistent across seasons than changes in response to modeled oyster biomass increase (Fig. 3, Table 3). Output of the Chesapeake Bay Water Quality Model (CBWQL; Cerco and Noel 2005) predicted that a 50\% nutrient load reduction would reduce phytoplankton biomass by a spring-summer average of $41 \%$. Our analysis, using reduced nutrient load as model input to generate this reduction in phytoplankton biomass resulted in a decline in phytoplankton TP of $28 \%$ in the spring and $17 \%$ in the summer in the tributaries (Fig. 3a, c, Table 3), compared to declines in phytoplankton TP ranging from $0 \%$ to $66 \%$ for the various oyster restoration scenarios.

Simulations predicted that a $50 \%$ reduction in nutrient load would lead to declines in springtime consumer TP that were comparable to all but the 50fold oyster increase (Fig. 3b, d, Table 3). The exceptions were sea nettles and ctenophores. Sea nettles had a predicted increase in production for oyster restoration and a decrease for reduced nutrient load. The pattern for ctenophores was reversed to that of sea nettles as a consequence of sea nettle predation on ctenophores. Declines in summer consumer TP resulting from oyster biomass increases were always substantially larger than those due to decreased nutrient load (Fig. 3d, Table 3). Standing stocks of ctenophores, meso-, and microzooplankton followed production and were reduced by similar amounts by nutrient reduction and a 10 -fold oyster biomass increase (Table 3 ).

The difference between the projected effects of a nutrient load reduction and oyster restoration on pelagic consumers is most evident in the effect on standing stocks. A $50 \%$ reduction in nutrient loads had little effect on average daily biomasses of zooplankton or bay anchovy; groups that decreased substantially with increasing oyster biomass (Fig. $4 \mathrm{a}-\mathrm{c}$ ). In general, forage 
fish biomass resulting from nutrient load reductions remained similar to that resulting from baseline oyster biomass in the simulated tributary (Table 3). The hypothesized increase in benthic habitat resulting from a decrease in the volume of hypoxic water in response to nutrient reductions yielded no trophic response in benthic invertebrates in the tributary. As a result there was also little predicted effect of a $50 \%$ reduction in nutrient load on benthic fishes.

\section{Model sensitivity analysis}

Removal of the model assumptions of a 1:1 relationship between resident reef fish and oyster biomass resulted in no appreciable change in spring TP for any functional group (Fig. 5a). Removal of this assumption resulted in a $0.8 \%$ increase in the effect of oysters on phytoplankton summer TP and a 6 to $39 \%$ increase in effect on consumer TP. Removal of the 1:1 relationship between reef-associated invertebrate and oyster biomass also resulted in minimal changes to estimates of spring production, but yielded a $15 \%$ decrease in the effect of oysters on phytoplankton summer TP and a 5-19\% decrease in the effect of oysters on consumer summer TP (Fig. 5b).

Removal of the assumption that increasing oyster habitat will increase sea nettle polyp production had strong effects on model predictions regarding gelatinous zooplankton but minimal effects on any other group. Late spring production of sea nettles was the primary driver of increased summer biomass of sea nettles, so a removal of the assumed increase in sea nettle biomass had a strong negative impact on sea nettles in the spring, which resulted in a positive impact on ctenophores in the summer. Removal of the sea nettle assumption reduced the effects of oysters on meso- and microzooplankton by $5 \%$.

\section{Discussion}

\section{Ecosystem effects of oyster restoration}

Restoration of once highly abundant stocks of suspension-feeding bivalves to estuaries and coastal waters has been proffered as a method for reducing some of the adverse effects of cultural eutrophication (Officer et al. 1982), increasing benthic primary and secondary production (Newell 2004), decreasing rates of nutrient regeneration (Newell et al. 2005), and decreasing the severity and extent of seasonal hypoxia (Newell 1988). Yet, the realized effect of oyster restoration on these factors has been called into question based on the seasonality and size selectivity of oyster filtration (Pomeroy et al. 2006, Fulford et al. 2007), as well as the spatial separation of nearshore oyster reefs from open water phytoplankton particularly in larger estuaries (Gerritsen et al. 1994). Our findings support the hypothesis that increased oyster biomass in the tributaries of Chesapeake Bay can reduce phytoplankton biomass and increase water clarity; however oyster biomass must be increased substantially (25- to 50 -fold

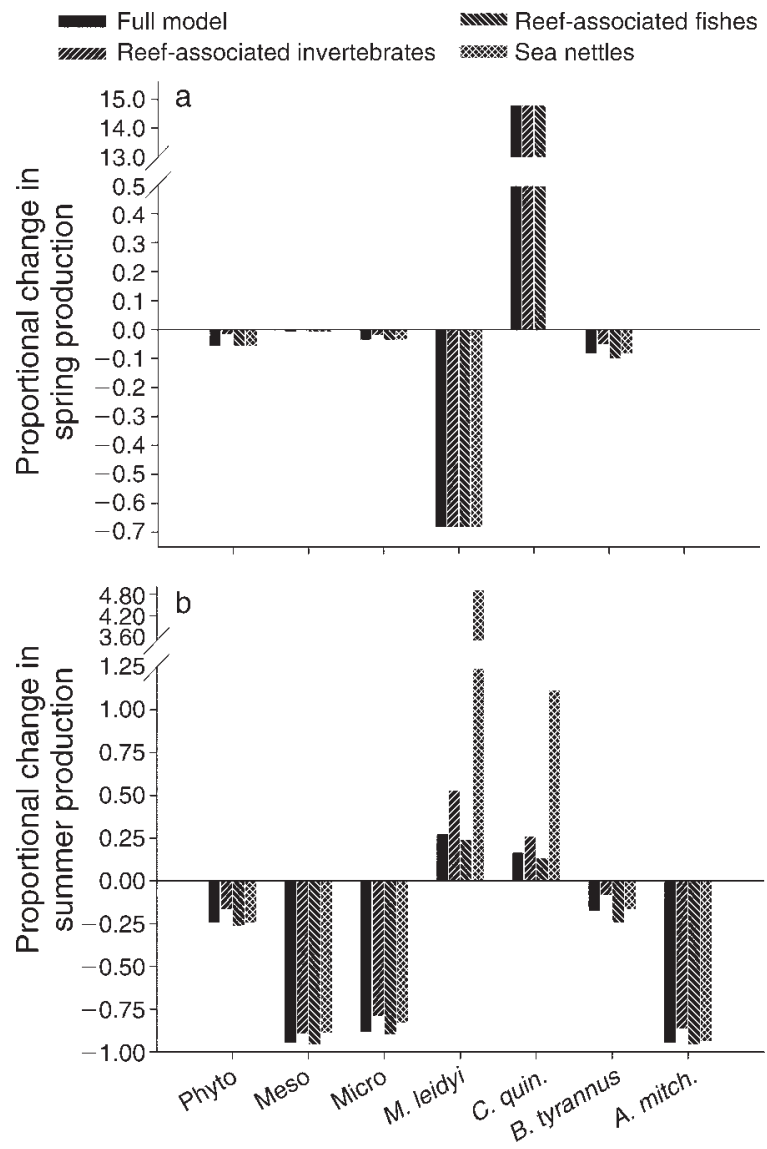

FIG. 5. Model sensitivity to assumptions for a $25 \times$ increase in oyster biomass. Sensitivity is measured as the difference in proportional change in total (a) spring and (b) summer production for the full model compared to a similar model run with each assumption removed. The three assumptions tested are an increase in reef-associated invertebrates, increase in reef-associated fishes, and increase in sea nettles. Key to abbreviations: Phyto, phytoplankton; all other abbreviations are as in Fig. 3.

current biomass) to realize meaningful improvement in these factors. Model results also suggest that increased oyster biomass will affect the food web horizontally and this must be considered alongside the beneficial effects of reversing eutrophication as a part of the overall ecosystem level response.

Oysters and primary production.-Increasing oyster biomass increased water clarity and decreased phytoplankton biomass in model simulations, but these beneficial impacts of oysters were seasonal and varied with phytoplankton cell size. These limitations largely narrowed the impact of oysters to the summer months when primary production is maximized and grazing pressure is already limiting to phytoplankton biomass (Malone 1992), and left the smaller size phytoplankton largely unaffected by oysters. During the period of maximum phytoplankton biomass (March-May), oyster filtration in the model was temperature-limited and not 
predicted to have an effect on phytoplankton biomass for any increase less than 50-fold current oyster biomass. During periods of maximum phytoplankton production (June-September), oysters were predicted to remove enough phytoplankton from the water column to affect phytoplankton biomass at all levels of oyster restoration, but it was only for the 50 -fold increase that total annual production of phytoplankton was reduced by more than $10 \%$. This seasonal imbalance between phytoplankton biomass and consumer grazing pressure was identified by Malone (1992) as a potentially important factor limiting top-down effects on eutrophication as the sequestration of nutrients resulting from the spring phytoplankton bloom is thought to provide an influx of nitrogen important to high summer production and the formation of hypoxic zones. Pomeroy et al. (2006) highlighted this seasonal imbalance as a key factor limiting the influence of oysters on summer hypoxia in the mainstem channel. Newell et al. (2007) pointed out important limitations to the conclusions of Pomeroy et al. (2006), but both studies do agree that grazer control of phytoplankton biomass occurs largely in the summer, after the incidence of the spring bloom.

Picoplankton $(<2 \mu \mathrm{m}$ ESD) is retained by oysters with a very low efficiency (Newell and Langdon 1996). As a result, our model predicted that with increasing oyster abundance picoplankton would comprise a small but increasing proportion of phytoplankton summer production. Increased picoplankton abundance would limit the effect of oysters on total primary production and provide a mechanism for increased horizontal trophic effects. The relative biomass of picoplankton typically increases in the summer in Chesapeake Bay and this trend has increased over the past 30 years (Kemp et al. 2005), which is a period of decreasing oyster abundance (Jordan et al. 2002). Picoplankton have also likely benefited from other changes in the Bay such as increased nutrient loads that favor phytoplankton size classes with the highest turnover rate.

One likely result of an increase in summer water clarity due to increased oyster filtration not considered in this analysis is an increased importance of benthic sources of primary production such as seagrasses and microphytobenthos. Model results are consistent with predictions that nutrients sequestered in the sediment during the late spring die-off of phytoplankton combined with increased light penetration would facilitate a summertime increase in the importance of benthic primary production.

The overall effect of oysters on pelagic primary production predicted by the model was an increase in summer water clarity, and some decline in summer phytoplankton biomass and production, which suggests that the eutrophication effect of excess nutrient delivery to Chesapeake Bay is reduced but not eliminated by oysters. Inorganic nutrient concentrations in the water column remain high and one likely result of a decrease in summer phytoplankton production is additional nutrient uptake by benthic primary producers in the summer. Taken in isolation this shift may be minor due to the limitations of oyster's direct effect on phytoplankton in the summer. However, an additional ecosystem level impact of oysters is some shift in sources of primary production along different trophic pathways, and this shift may act synergistically with horizontal effects of oysters on other consumers.

Oysters and secondary production.-Model predictions suggest that consumer biomass and production are more sensitive to oyster restoration than are phytoplankton biomass and production. This was most evident for the two zooplankton groups that compete directly with oysters for phytoplankton. Resource limitation was manifested as a reduction in specific consumption by both mesozooplankton and microzooplankton as oyster biomass increased, as well as large decreases of phytoplankton in size classes with high vulnerability to all three consumer groups (2-10 $\mu \mathrm{m})$.

The impact of oysters on zooplankton in the model simulations was due largely to increased consumption of phytoplankton that was already grazer limited. Yet, the effect was greater than might be expected as a result of two important feedback loops we included in the model: foraging flexibility of mesozooplankton and the reproductive link between mesozooplankton and microzooplankton pools. An intraguild predation relationship existed in the model between mesozooplankton, microzooplankton, and phytoplankton, as mesozooplankton could prey upon both of the other groups in response to shifts in relative abundance. This interaction resulted in a gradual increase in the importance of microzooplankton as a prey item for mesozooplankton as oyster biomass increased due to increased oyster grazing pressure on phytoplankton. Intraguild predation has been found to ameliorate bottom-up effects in aquatic food webs (Hart 2002), and two factors make that likely to be important in this case. First, meso- and microzooplankton also have a reproductive link in that copepod nauplii are included in the microzooplankton group, resulting in a cannibalism effect as mesozooplankton prey more heavily on microzooplankton. Cannibalism has been found to be negatively associated with phytoplankton density in $A$. tonsa in laboratory experiments (Lemus 2006) and has been reported to be important in natural populations of several Acartia species (Uye and Liang 1998, Ara 2001). The relative importance of nauplii to overall microzooplankton biomass is large in the summer and this reproductive link yields a larger effect of mesozooplankton on their own production than would be present if nauplii were not considered a prey item.

The second and more important factor enhancing the influence of intraguild predation was a difference between oysters and zooplankton in prey ingestion efficiency. Oysters remove far more phytoplankton 
biomass from the water column than they require to meet their energetic needs. The excess organic material is sequestered in sediments as pseudofeces (Newell and Langdon 1996). Our model predicts that when phytoplankton biomass is reduced, mesozooplankton respond first by shifting consumption to microzooplankton and then by reducing mesozoopankton daily gross production, while oysters responded by maintaining near maximum filtration and producing less pseudofeces. This difference yields a disproportionate impact on zooplankton production, which, because of the short generation time compared with oysters, responds to reductions in prey biomass at a much shorter time scale.

The validity of these model-based observations depends on the level of realized overlap in prey resources between oysters and zooplankton. Complete removal of zooplankton by oysters in Chesapeake Bay is unlikely because the plankton pool is not fully accessible to oysters, which are confined to oyster reefs on the flanks of the tributaries and the mainstem of the Bay (Smith et al. 2003). In contrast, zooplankton live throughout the water column and across the central channel of the Bay and tributaries. The magnitude of this model prediction is therefore a result of simplifying assumptions. Nonetheless, our results suggest that a balance between consumer groups does exist and the increase in abundance of a once dominant benthic grazer will result in reallocation of phytoplankton carbon along different trophic pathways.

Similar issues have been raised in the examination of bivalve populations in other systems. Nielsen and Maar (2007) found that zooplankton populations were significantly smaller over beds of the blue mussel, Mytilus edulis, when compared to sandy bottom and they attributed this to both predation and competitive interactions between the mussels and zooplankton. A model-based examination of the effect of oyster culture on the pelagic food web in Marennes-Oleron Bay, France revealed a strong competitive interaction between oysters and pelagic consumers that resulted in a shift in overall secondary production from the water column to the benthos (Leguerrier et al. 2004).

The influence of oysters on other planktivores in TroSim simulations was translated up the food chain and the importance of foraging flexibility in predicting the ecosystem effects of increased oyster biomass was demonstrated by the difference in effect on the two modeled pelagic fish groups. Ostensibly, menhaden should have been affected similarly to zooplankton because they also consume phytoplankton. However, the inclusion of POC as a prey item for menhaden allowed this consumer group to benefit from phytoplankton production that had already passed through other consumer pools (i.e., fecal material). The result is that the only limitation on menhaden consumption in the model was sequestration of carbon in the sediment, and the inclusion of reasonable resuspension dynamics minimized this limitation for all but the highest increases in oyster biomass. In contrast, the zooplanktivorous bay anchovy were limited to mesozooplankton and microzooplankton prey and effects of oysters on these two groups was transferred up the food chain in a linear manner.

The overall predicted effect in response to varying levels of oyster biomass increase was a 50-80\% reduction in pelagic prey fish biomass and a $28-190 \%$ increase in benthic fish biomass. The magnitude of increase in benthic fish biomass is questionable as this increase is heavily influenced by assumptions regarding the positive influence of oysters on oyster reef biota, and the model does not consider the influence of summer hypoxia. Nonetheless, a positive influence is expected, particularly in combination with an increase in water clarity, which should increase benthic primary production and reduce hypoxic coverage. These model predictions support the conclusion that increasing oyster biomass can facilitate a shift in the relative importance of benthic and pelagic trophic pathways.

This predicted shift from pelagic to benthic trophic pathways may extend up the food web to commercially important apical consumers such as striped bass (Morone saxatilis), bluefish (Pomatomus saltatrix), and blue crab (Callinectes sapidus) to the degree to which they can directly or indirectly exploit benthic production. For example, bluefish in Chesapeake Bay are thought to rely indirectly on benthic production (Baird and Ulanowicz 1989) and examinations of striped bass show their diet to be dominated by pelagic fish, but seasonally flexible, as they feed on benthic invertebrates when they are abundant (Hartman and Brandt 1995). A reduction in the dominance of pelagic prey fishes may not be a significant loss to bluefish or striped bass if they are able to shift to benthic trophic pathways. Apical fish consumers were not explicitly included in our TroSim model. Our conclusions are based on impacts on the forage fish production surplus and do not consider possible synergistic effects of top-down control and the predicted effects of oysters on pelagic prey fishes. The most important outcome of inclusion of these synergistic effects would be an explicit examination of trophic effect of the predicted benthic-pelagic shift in production on particular consumer species, which would have implications for fishery exploitation. However, apical consumer influence was considered in the production surplus that favored benthic fish production at all levels of oyster biomass increase.

The one pelagic predator that benefited from oyster biomass increases was sea nettles. Sea nettle numbers were assumed to increase based on an apparent temporal association between oyster biomass and sea nettle abundance over the last twenty years (Breitburg and Fulford 2006), as well as data showing a strong affinity of sea nettle polyps for oyster shell as settlement habitat (Cargo 1979). The influence of this assumption on trophic dynamics was almost entirely contained within the gelatinous zooplankton. Total gelatinous 
zooplankton biomass declined $30-90 \%$ in response to increased oyster biomass due to high predation of sea nettles on ctenophores, which are a major prey item. Both ctenophores and sea nettles prey on mesozooplankton but ctenophores have a higher feeding rate, so the effect of this tradeoff on plankton production was positive. However, the positive effect of oysters on polyp densities was ameliorated by reduced medusoid production at the highest level of oyster biomass resulting from reduced prey production. Although we did not run simulations of larger increases in oyster biomass (e.g., pre-20th-century levels of 100-1000-fold present day abundances), our model predictions suggest that high sea nettle densities in Chesapeake Bay could be supported at oyster biomass characteristic of the mid20th century, but not the much higher oyster biomass typical of the 19th century and earlier. This conclusion is consistent with an analysis of historical reports that suggests sea nettles were far less common in the 19th century than they are today (Kennedy and Mountford 2001).

\section{Comparison of oyster restoration to nutrient reduction}

Predicted effects of a $50 \%$ reduction in nutrients on producer and consumer biomass and production differed qualitatively as well as quantitatively from predictions of oyster restoration. The most important difference was seasonal; effects of nutrient reduction were important in both the spring and summer period while effects of moderate levels of oyster restoration were important primarily in the summer. As a result, annual mean phytoplankton biomass in the nutrient reduction scenario was predicted to be lower than all but a 50 -fold increase in oyster biomass in the tributary simulations.

For planktonic consumers and planktivorous forage fishes, TroSim predicted that a larger and more consistent decrease in production and biomass would result from oyster biomass increases than from reductions in nutrient load. The bottom-up effects of nutrient load reduction were evident as a reduction in accumulated phytoplankton biomass in the summer but the importance of this reduction to consumers was predicted to be less than the influence of a summer increase in grazing pressure. The differences are even more stark when one considered that oyster impacts on summer phytoplankton biomass were strongly focused in two size classes while reductions in phytoplankton production due to reduced nutrients were fairly even across size groups. This difference was important to the model prediction that oyster restoration will have a larger impact on consumer biomass in comparison to nutrient load reduction.

Our current simulations are focused on the pelagic component of the food web and as already discussed do not fully consider the potential compensatory effects of increased benthic primary production that may result from both increased light penetration and decreased hypoxia. These responses may moderate effects of nutrient reduction on benthos-influenced food web pathways. However, we did run sensitivity tests in which biomass of soft-bottom invertebrates was increased, a likely outcome of decreased hypoxia and increased microphytobenthos production. These results indicate that a shift in the forage base for top piscivores to benthivorous prey resulting from reductions in the incidence and severity of bottom-water hypoxia would likely have a minor effect on overall biomass available to these apical predators. The simulated $13 \%$ increase in benthic habitat increased benthic fish production by $9 \%$, an increase that was far smaller than the loss of pelagic fish production resulting from a $50 \%$ reduction in nutrient loadings. The spatial extent of hypoxia varies greatly among Chesapeake Bay tributaries, but for most tributaries the potential increase in benthic habitat is expected to be similar to or less than predicted by our simulations.

\section{TroSim model complexity}

Tradeoffs between different forms of model complexity mean that while TroSim captures the effects of seasonality of primary production, size-selective filtration efficiency, and diet flexibility of consumers, it does not explicitly consider important processes such as hydrodynamic factors, changes in nutrient recycling rates, or hypoxia. Some extreme predictions of consumer effect such as the large impact of oysters on zooplankton and zooplanktivorous fishes are likely overestimates resulting from a lack of hydrodynamic complexity.

Spatial separation of consumers and prey resulting from hydrodynamics and system size are more likely to confound simulation results for the mainstem of the Bay (Appendix C) than the tributary simulations we discuss here. Gerritsen et al. (1994) developed a simple probability-based mixing model and estimates that the percentage of the surface mixed layer available to suspension feeding benthic organisms varied between $16 \%$ in the mainstem of Chesapeake Bay to $100 \%$ in the Potomac River (the second largest tributary of Chesapeake Bay) so the actual influence of hydrodynamics on our predictions in the tributary may be low. The overall applicability of our model predictions to the entire Bay will be dependent on how much spatial complexity matters baywide and how much mainstem trophic dynamics are linked to energy flow in the tributaries. Most oyster restoration is or is planned to be in the tributaries and results of this tributary model are relevant to predicting ecosystem effects of such restoration.

Our future goals include linking TroSim simulations for the mainstem of Chesapeake Bay and the tributaries together with a hydrodynamics model, which will produce a more realistic picture of tributary and bay connectivity. Nonetheless, the seasonal patterns and comparative results are robust to these simplifying 
assumptions. Predictions from the current model suggest that effects of oyster restoration on pelagic consumers are likely to be important, and that there are important ecological differences between the effects of bivalve restoration and the effects of reducing nutrient loads as management actions.

\section{TroSim comparison to other models and model predictions}

The effect of bivalves on food web dynamics has been examined in several systems, however the focus has largely been on changes in benthic-pelagic coupling and improvements in water quality (Cloern 1982, Dame 1996, Newell et al. 2005). These papers frame the debate about the ecosystem services of bivalves largely without consideration of effects on other consumers. Two published models (Ulanowicz and Tuttle 1992, Cerco and Noel 2005) do directly address oyster restoration in Chesapeake Bay, and both predicted stronger effects of increased oyster abundance on reducing phytoplankton biomass than the current TroSim model. The Cerco and Noel (2005) model predicted a $6 \%$ reduction in annual mean chlorophyll $a$ concentration for a 10 -fold increase in oyster biomass throughout the northern half of Chesapeake Bay. Their model does include phytoplankton consumption from other consumers, but does not include a full suite of other grazers. Ulanowicz and Tuttle (1992) predicted an $11.5 \%$ reduction in annual mean phytoplankton biomass from a 2.5 -fold increase in oyster biomass in the mesohaline mainstem of the Bay in contrast to our prediction of a $2-23 \%$ reduction in annual mean biomass from a 10 - to 50 -fold increase. The network model analysis of oyster restoration conducted by Ulanowicz and Tuttle (1992) also deviated from our predictions in suggesting that oyster restoration would have a positive effect on fish production, and a negative effect on gelatinous zooplankton. The primary difference between this analysis and that of Ulanowicz and Tuttle (1992) is that our analysis considered both trophic and habitat effects on consumer groups and incorporated both realistic seasonality and diet flexibility. These differences result in the altered conclusion that oysters may have appreciable effects on pelagic secondary production that should be considered when evaluating the effects on water quality and benthic primary production.

\section{Bivalve restoration as an ecosystem management tool}

Model predictions should be viewed in the context of high nutrient loads and low oyster populations that currently prevail in Chesapeake Bay. We do not mean to imply that recovery to high oyster abundances would preclude the abundant biota that characterized Chesapeake Bay prior to substantial fisheries exploitation and anthropogenic nutrient enrichment, but that pelagic trophic pathways were likely less important then. In the 19th century, both fish and oyster abundances were high and nutrient enrichment was relatively low
(Newell 1988), suggesting these conditions are not mutually exclusive.

In a comparison of estuaries along the U.S. east coast, Monaco and Ulanowicz (1997) theorized that higher trophic level fishes are more strongly connected to benthic production in Chesapeake Bay than in other estuaries due largely to higher dependence on detritus. In addition, Hartman (1993) used a bioenergetics model to conclude that weakfish (Cynoscion regalis), bluefish, and striped bass all increased their trophic dependence on benthic prey in the summer and this trend was most obvious for two-year-old striped bass. These findings suggest despite the current importance of the pelagic production in Chesapeake Bay, an increase in the importance of benthic production to apical consumers is a feasible response to system alteration.

Chesapeake Bay has been greatly altered by human activities and our model results support the broadly held view that oyster restoration alone can not return the Bay to pristine conditions thought to exist prior to the 20th century. Yet, oysters have the potential to greatly alter the Bay food web and the impact of these changes on fisheries production should be considered. If model predictions are accurate in direction, if not magnitude, then exploited fish species that are benthic and/or can exploit benthic prey will benefit from oyster restoration more than fish species dependent on pelagic prey, and harvest of these species could benefit from oyster restoration.

It is apparent that oyster restoration must be achieved at levels significantly higher than present biomass and present management targets in Chesapeake Bay to have a meaningful effect on ecosystem function, including pelagic primary productivity and biomass (Cerco and Noel 2005, Fulford et al. 2007). The results of this study indicate that such large increases in oyster biomass could strongly alter current pelagic consumer biomass. Overall, the predicted trophic response of the Chesapeake Bay system to oyster restoration suggests that water quality goals represent a trade-off in the relative importance of pelagic and benthic trophic pathways. This trade off is further complicated by deliberate manipulations of present pelagic consumer biomass via fishing. Understanding such trade-offs are at the heart of ecosystem-based management and merit greater scrutiny in the development of management plans for coastal estuaries.

\section{ACKNOWLEDGMENTS}

This work would not have been possible without the assistance of many people with data compilation, model development, and model interpretation, including Steve Bartell, Michael Kemp, Carl Cerco, Charles Gallegos, Michael Roman, David Kimmel, Cindy Gilmour, Raleigh Hood, Kevin Sellner, Wayne Coats, and Claire Buchanan. This project was also highly dependent on data collected and analyzed as a part of the Chesapeake Bay Program (CBP), and we thank David Jasinski (CBP), Jeni Keisman (UMCES/ $\mathrm{CBP}$ ), and all those involved in making these data available. 
This project was funded by grants from the EPA Chesapeake Bay Program and the NOAA Coastal Ocean Program.

\section{Literature Cited}

Abbe, G. R. 1992. Population structure of the eastern oyster, Crassostrea virginica, on two oyster bars in central Chesapeake Bay: further changes associated with shell planting, recruitment and disease. Journal of Shellfish Research 11: 421-430.

Ara, K. 2001. Daily egg production rate of the planktonic calanoid copepod, Acartia lilljeborgi (Giesbrecht), in the Cananeia Lagoon estuarine system, São Paulo, Brazil. Hydrobiologia 445:205-215.

Baird, D., and R. E. Ulanowicz. 1989. The seasonal dynamics of the Chesapeake Bay ecosystem. Ecological Monographs 59:329-364.

Banse, K. 1982. Cell volumes, maximal growth rates of unicellular algae and ciliates, and the role of ciliates in the marine pelagial. Limnology and Oceanography 27:10591071.

Bartell, S. M. 2003. A framework for estimating ecological risks posed by nutrients and trace elements in the Patuxent River. Estuaries 26:385-397.

Bartell, S. M., G. Lefebvre, G. Kaminski, M. Carreau, and K. R. Campbell. 1999. An ecosystem model for assessing ecological risks in Quebec rivers, lakes, and reservoirs. Ecological Modelling 124:43-67.

Beaulieu, S. E. 2003. Resuspension of phytodetritus from the sea floor: a laboratory flume study. Limnology and Oceanography 48:1235-1244.

Boicourt, B. L. 1992. The influences of circulation processes on dissolved oxygen in Chesapeake Bay. Pages 7-59 in D. Smith, M. Leffler, and G. Mackiernan, editors. Dissolved oxygen in Chesapeake Bay. Maryland Sea Grant, College Park, Maryland, USA.

Breitburg, D. L. 1990. Nearshore hypoxia in the Chesapeake Bay: patterns and relationships among physical factors. Estuarine Coastal and Shelf Science 30:593-609.

Breitburg, D. L., and R. S. Fulford. 2006. Oyster-sea nettle interdependence and altered control within the Chesapeake Bay ecosystem. Estuaries and Coasts 29:776-784.

Breitburg, D. L., M. A. Palmer, and T. Loher. 1995. Effects of flow, structure and larval schooling behavior on settlement behavior of oyster reef fish. Marine Ecology Progress Series 125:45-60.

Brumbaugh, R. D., L. A. Sorabella, C. O. Garcia, W. J. Goldsborough, and J. A. Wesson. 2000. Making a case for community-based oyster restoration: an example from Hampton Roads, Virginia, USA. Journal of Shellfish Research 19:467-472.

Cargo, D. G. 1979. Observations on the settling behavior of planular larvae of Chrysaora quinquecirrha. International Journal of Invertebrate Reproduction 1:279-287.

Carpenter, S. R., D. L. Christensen, J. J. Cole, K. L. Cottingham, X. He, J. R. Hodgson, J. F. Kitchell, S. E. Knight, M. L. Pace, D. M. Post, D. E. Schindler, and N. Voichick. 1995. Biological-control of eutrophication in lakes. Environmental Science and Technology 29:784-786.

Carpenter, S. R., J. J. Cole, J. R. Hodgson, J. F. Kitchell, M. L. Pace, D. Bade, K. L. Cottingham, T. E. Essington, J. N. Houser, and D. E. Schindler. 2001. Trophic cascades, nutrients, and lake productivity: whole-lake experiments. Ecological Monographs 71:163-186.

Cerco, C. F., and M. R. Noel. 2005. Evaluating ecosystem effects of oyster restoration in Chesapeake Bay. Report submitted to Maryland Department of Natural Resources, Annapolis, Maryland, USA.

Cloern, J. E. 1982. Does the benthos control phytoplankton biomass in south San Francisco Bay? Marine Ecology Progress Series 9:191-202.
Cloern, J. E. 2001. Our evolving conceptual model of the coastal eutrophication problem. Marine Ecology Progress Series 210:223-253.

Coen, L. D., R. D. Brumbaugh, G. R. D. Bushek, M. W. Luckenbach, M. Posey, S. P. Powers, and S. G. Tolley. 2007. Ecosystem services related to oyster restoration. Marine Ecology Progress Series 34:303-307.

Coen, L. D., M. W. Luckenbach, and D. L. Breitburg. 1999. The role of oyster reefs as essential fish habitat: A review of current knowledge and some new perspectives. American Fisheries Society Symposium 22:438-454.

Correll, D. L., T. E. Jordan, and D. E. Weller. 1999. Transport of nitrogen and phosphorus from Rhode River watersheds during storm events. Water Resources Research 35:25132521.

Correll, D. L., T. E. Jordan, and D. E. Weller. 2000. Transfer of phosphorus from the farm to the bay. Pages 131-142 in A. N. Sharpley, editor. Agriculture and phosphorus management: the Chesapeake Bay. Lewis Publishers, Washington, D.C., USA.

Cressman, K. A., M. H. Posey, M. A. Mallin, L. A. Leonard, and T. D. Alphin. 2003. Effects of oyster reefs on water quality in a tidal creek estuary. Journal of Shellfish Research 22:753-762.

Dame, R. F. 1996. Ecology of marine bivalves: an ecosystem approach. CRC Press, Boca Raton, Florida, USA.

Environmental Protection Agency. 2000. Chesapeake 2000 bay agreement. U.S. EPA Chesapeake Bay Program, Annapolis, Maryland, USA.

Fear, J., T. Gallo, N. Hall, J. Loftin, and H. Paerl. 2004. Predicting benthic microalgal oxygen and nutrient flux responses to a nutrient reduction management strategy for the eutrophic Neuse River Estuary, North Carolina, USA. Estuarine Coastal and Shelf Science 61:491-506.

Fulford, R. S., D. L. Breitburg, R. I. E. Newell, W. M. Kemp, and M. W. Luckenbach. 2007. Effects of oyster population restoration strategies on phytoplankton biomass in Chesapeake Bay: a flexible modeling approach. Marine Ecology Progress Series 336:43-61.

Gallegos, C. L. 2001. Calculating optical water quality targets to restore and protect submersed aquatic vegetation: overcoming problems in partitioning the diffuse attenuation coefficient for photosynthetically active radiation. Estuaries 24:381-397.

Gerritsen, J., A. F. Holland, and D. E. Irvine. 1994. Suspension-feeding bivalves and the fate of primary production: an estuarine model applied to Chesapeake Bay. Estuaries 17:403-416.

Giles, H., and C. A. Pilditch. 2004. Effects of diet on sinking rates and erosion thresholds of mussel Perna canaliculus biodeposits. Marine Ecology Progress Series 282:205-219.

Grove, M., and D. L. Breitburg. 2005. Growth and reproduction of gelatinous zooplankton exposed to low dissolved oxygen. Marine Ecology Progress Series 301:185-198.

Hagy, J. D. 2002. Eutrophication, hypoxia and trophic transfer efficiency in Chesapeake Bay. Dissertation. University of Maryland, College Park, Maryland, USA.

Hagy, J. D., W. R. Boynton, C. W. Keefe, and K. V. Wood. 2004. Hypoxia in Chesapeake Bay, 1950-2001: long-term change in relation to nutrient loading and river flow. Estuaries 27:634-658.

Harding, J. M., and R. Mann. 1999. Fish species richness in relation to restored oyster reefs, Piankatank River, Virginia. Bulletin of Marine Science 65:289-299.

Hart, D. R. 2002. Intraguild predation, invertebrate predators, and trophic cascades. Journal of Theoretical Biology 218: 111-128.

Hartman, K. J. 1993. Striped bass, bluefish, and weakfish in the Chesapeake Bay. Energetics, trophic linkages, and bioenergetics model applications. Dissertation. University of Maryland, College Park, Maryland, USA. 
Hartman, K. J., and S. B. Brandt. 1995. Trophic resource partitioning, diets, and growth of sympatric estuarine predators. Transactions of the American Fisheries Society 124:520-537.

Holyoke, R. R. 2008. Biodeposition and biogeochemical processes in shallow, mesohaline sediments of Chesapeake Bay. Dissertation. University of Maryland, College Park, Maryland, USA.

Jordan, S. J., and J. M. Coakley. 2004. Long-term projections of eastern oyster populations under various management scenarios. Journal of Shellfish Research 23:63-72.

Jordan, S. J., K. N. Greenhawk, C. B. McCollough, J. Vanisko, and M. L. Homer. 2002. Oyster biomass, abundance, and harvest in northern Chesapeake Bay: trends and forecasts. Journal of Shellfish Research 21:733-741.

Jordan, T. E., D. F. Whigham, K. H. Hofmockel, and M. A. Pittek. 2003. Nutrient and sediment removal by a restored wetland receiving agricultural runoff. Journal of Environmental Quality 32:1534-1547.

Jung, S. 2002. Fish community structure and the spatial and temporal variability in recruitment and biomass production in Chesapeake Bay. Dissertation. University of Maryland, College Park, Maryland, USA.

Jung, S., and E. D. Houde. 2004. Recruitment and spawningstock biomass distribution of bay anchovy (Anchoa mitchilli) in Chesapeake Bay. Fishery Bulletin 102:63-77.

Kemp, W. M., et al. 2005. Eutrophication of Chesapeake Bay: historical trends and ecological interactions. Marine Ecology Progress Series 303:1-29.

Kemp, W. M., W. R. Boynton, J. C. Stevenson, R. R. Twilley, and J. C. Means. 1983. The decline of submerged vascular plants in upper Chesapeake Bay: summary of results concerning possible causes. Marine Technological Society Journal 17:78-89.

Kennedy, V. S. 1996. Biology of larvae and spat. Pages 371-421 in V. S. Kennedy, R. I. E. Newell, and A. Eble, editors. The eastern oyster, Crassostrea virginica. Maryland Sea Grant, College Park, Maryland, USA.

Kennedy, V. S., and K. Mountford. 2001. Human influences on aquatic resources in the Chesapeake Bay watershed. Pages 191-219 in P. D. Curtin, G. Brush, and G. W. Fisher, editors. Discovering the Chesapeake. Johns Hopkins University Press, Baltimore, Maryland, USA.

Kimmel, D. G., and M. R. Roman. 2004. Long-term trends in mesozooplankton abundance in Chesapeake Bay, USA: influence of freshwater input. Marine Ecology Progress Series 267:71-83.

Leguerrier, D., N. Niquil, A. Petiau, and A. Bodoy. 2004. Modeling the impact of oyster culture on a mudflat food web in Marennes-Oleron Bay (France). Marine Ecology Progress Series 273:147-161.

Lemus, J. T. 2006. The effect of copepod density on cannibalism, survival, development rate and egg production and the implications for population growth rate and demographics of Acartia tonsa Dana (Copepoda: Calanoida). Dissertation. University of Southern Mississippi, Ocean Springs, Mississippi, USA.

Luckenbach, M. W., L. D. Coen, P. G. Ross, and J. A. Stephen. 2005. Oyster reef habitat restoration: relationships between oyster abundance and community development based on two studies in Virginia and South Carolina. Journal of Coastal Research 40:64-78.

MacKenzie, C. L., Jr., V. G. Burrell, Jr., A. Rosenfield, and W. L. Hobart. 1997. The history, present condition, and future of the molluscan fisheries of North America and Europe. Volume 1, Atlantic and Gulf Coasts. NOAA Technical Report NMFS 127. National Oceanic and Atmospheric Administration, Washington, D.C., USA.

Malone, T. C. 1992. Effects of water column processes on dissolved oxygen, nutrients, phytoplankton, and zooplankton. Pages 61-112 in D. E. Smith, M. Leffler, and G.
Mackiernan, editors. Oxygen dynamics in the Chesapeake Bay. Maryland Sea Grant College, College Park, Maryland, USA.

Miller, T. J. 2004. Chesapeake Bay fishery-independent multispecies survey. NOAA-Chesapeake Bay Office, Annapolis, Maryland, USA.

Monaco, M. E., and R. E. Ulanowicz. 1997. Comparative ecosystem trophic structure of three US mid-Atlantic estuaries. Marine Ecology-Progress Series 161:239-254.

Moser, M. L., and W. F. Hettler. 1989. Routine metabolism of juvenile spot, Leiostomus xanthurus (Lacepede), as a function of temperature, salinity and weight. Journal of Fish Biology 35:703-707.

Murdy, E. O., R. A. Birdsong, and J. A. Musick. 1997. Fishes of Chesapeake Bay. Smithsonian Institution Press, Washington, D.C., USA.

Nakamura, Y., and F. Kerciku. 2000. Effects of filter-feeding bivalves on the distribution of water quality and nutrient cycling in a eutrophic coastal lagoon. Journal of Marine Systems 26:209-221.

National Marine Fisheries Service. 1999. Ecosystem-based fisheries management. A report to Congress by the Ecosystems Principles Advisory Panel. National Marine Fisheries Service, Washington, D.C., USA.

National Research Council. 2004. Nonnative oysters in Chesapeake Bay. The National Academies Press, Washington, D.C., USA.

Neumann, T., and G. Schemewski. 2005. An ecological model evaluation of two nutrient abatement strategies for the Baltic Sea. Journal of Marine Systems 56:195-206.

Newell, R. I. E. 1988. Ecological changes in Chesapeake Bay: Are they the result of overharvesting the American oyster, Crassostrea virginica? Pages 536-546 in M. P. Lynch and E. C. Krome, editors. Understanding the estuary: advances in Chesapeake Bay research. Chesapeake Research Consortium, Gloucester Point, Virginia, USA.

Newell, R. I. E. 2004. Ecosystem influences of natural and cultivated populations of suspension-feeding bivalve molluscs: a review. Journal of Shellfish Research 23:51-61.

Newell, R. I. E., T. R. Fisher, R. R. Holyoke, and J. C. Cornwell. 2005. Influence of eastern oysters on nitrogen and phosphorus regeneration in Chesapeake Bay, USA. Pages 93-120 in R. Dame and S. Olenin, editors. The comparative roles of suspension feeders in ecosystems. Springer, Dordrecht, The Netherlands.

Newell, R. I. E., W. M. Kemp, J. D. Hagy III, C. F. Cerco, J. M. Testa, and W. R. Boynton. 2007. Top down control of phytoplankton by oysters in Chesapeake Bay, USA: Comment on Pomeroy et al. (2006). Marine Ecology Progress Series 341:293-298.

Newell, R. I. E., and C. J. Langdon. 1996. Mechanisms and physiology of larval and adult feeding. Pages 185-230 in V. S. Kennedy, R. I. E. Newell, and A. F. Eble, editors. The eastern oyster Crassostrea virginica. Maryland Sea Grant College, College Park, Maryland, USA.

Newell, R. I. E., and J. Ott. 1998. Macrobenthic communities and eutrophication. Pages 265-293 in T. C. Malone, A. Malej, L. W. Harding, N. Smodlaka, and R. E. Turner, editors. Ecosystems at the land-sea margin: drainage basin to coastal sea. Coastal and Estuarine Studies, Volume 55. American Geophysical Union, Washington, D.C., USA.

Nielsen, T. G., and M. Maar. 2007. Effects of a blue mussel, Mytilus edulis, bed on vertical distribution and composition of the pelagic food web. Marine Ecology Progress Series 339: 185-198.

Nixon, S. W. 1995. Coastal marine eutrophication: a definition, social causes, and future concerns. Ophelia 41:199-219.

North, E. W., S. Y. Chao, L. P. Sanford, and R. R. Hood. 2004. The influence of wind and river pulses on an estuarine turbidity maximum: numerical studies and field observations in Chesapeake Bay. Estuaries 27:132-146. 
Officer, C. B., T. J. Smayda, and R. Mann. 1982. Benthic filter feeding, a natural eutrophication control. Marine Ecology Progress Series 9:203-210.

Orth, R. J., R. A. Batiuk, P. W. Bergstrom, and K. A. Moore. 2002. A perspective on two decades of policies and regulations influencing the protection and restoration of submerged aquatic vegetation in Chesapeake Bay, USA. Bulletin of Marine Science 71:1391-1403.

Orth, R. J., and K. A. Moore. 1983. Chesapeake Bay: an unprecedented decline in submerged aquatic vegetation. Science 222:51-53.

Paloheimo, J. E. 1979. Indices of food type preference by a predator. Journal of the Fisheries Research Board of Canada 36:470-473.

Pomeroy, L. R., C. F. D'Elia, and L. C. Schaffner. 2006. Limits to top-down control of phytoplankton by oysters in Chesapeake Bay. Marine Ecology Progress Series 325:301309.

Ptacnik, R., G. Jenerette, A. M. Verschoor, A. F. Huberty, A. G. Solimini, and J. D. Brookes. 2005. Applications of ecological stoichiometry for sustainable acquisition of ecosystem services. Oikos 109:52-62.

Purcell, J. E., D. A. Nemazie, S. E. Dorsey, E. D. Houde, and J. C. Gamble. 1994a. Predation mortality of bay anchovy, Anchoa mitchilli, eggs and larvae due to scyphomedusae and ctenophores in Chesapeake Bay. Marine Ecology Progress Series 114:47-58

Purcell, J. E., J. R. White, and M. R. Roman. 1994b. Predation by gelatinous zooplankton and resource limitation as potential controls of Acartia tonsa copepod populations in Chesapeake Bay. Limnology and Oceanography 39:263-278.

Rodney, W. S., and K. T. Paynter. 2006. Comparisons of macrofaunal assemblages on restored and non-restored oyster reefs in mesohaline regions of Chesapeake Bay in Maryland. Journal of Experimental Marine Biology and Ecology 335:39-51.
Smith, G. F., E. B. Roach, and D. G. Bruce. 2003. The location, composition, and origin of oyster bars in mesohaline Chesapeake Bay. Estuarine Coastal and Shelf Science 56: 391-409.

Souchu, P., A. Vaquer, Y. Collos, S. Landrein, J. DeslousPaoli, and B. Bibent. 2001. Influence of shellfish farming activities on the biogeochemical composition of the water column in Thau lagoon. Marine Ecology Progress Series 218: $141-152$.

Tang, E. P. Y. 1995. The allometry of algal growth rates. Journal of Plankton Research 17:1325-1335.

Testa, J. M., W. M. Kemp, W. R. Boynton, and J. D. Hagy III. 2008. Long-term changes in water quality and productivity in the Patuxent river estuary: 1985-2003. Estuaries and Coasts 31:1021-1037.

Ulanowicz, R. E., and J. H. Tuttle. 1992. The trophic consequences of oyster stock rehabilitation in Chesapeake Bay. Estuaries 15:298-306.

Uye, S. I., and D. Liang. 1998. Copepods attain high abundance, biomass and production in the absence of large predators but suffer cannibalistic loss. Journal of Marine Systems 15:1-4.

Walters, C. J., and F. Juanes. 1993. Recruitment limitation as a consequence of natural-selection for use of restricted feeding habitats and predation risk-taking by juvenile fishes. Canadian Journal of Fisheries and Aquatic Sciences 50: 2058-2070.

Wang, S. B., and E. D. Houde. 1994. Energy storage and dynamics in bay anchovy, Anchoa mitchilli. Marine Biology 121:121-219.

Wang, S. B., and E. D. Houde. 1995. Distribution, relative abundance, biomass, and production of bay anchovy, Anchoa mitchilli, in the Chesapeake Bay. Marine Ecology Progress Series 121:27-38.

\section{APPENDIX A}

TroSim: description of supplementary functions and parameters (Ecological Archives A020-031-A1).

\section{APPENDIX B}

TroSim: model validation for Chesapeake Bay simulations (Ecological Archives A020-031-A2).

\section{APPENDIX C}

TroSim: summary data for simulations for mesohaline section of mainstem of Chesapeake Bay (Ecological Archives A020-031A3). 